\title{
Design, Synthesis, and In Vitro/In Vivo Anti-Cancer Activities of Novel (20S)-10,11-Methylenedioxy- Camptothecin Heterocyclic Derivatives
}

\author{
Xiufen Dai ${ }^{1,+}$, Guanzhao $\mathrm{Wu}^{1,+}{ }^{\dagger}$, Yixuan Zhang ${ }^{1}$, Xiaomin Zhang ${ }^{1,2}$, Ruijuan Yin ${ }^{1}$, Xin Qi ${ }^{1, *}$, \\ Jing $\mathrm{Li}^{1,2, *}$ and Tao Jiang ${ }^{1,2}$ \\ 1 Key Laboratory of Marine Drugs, Ministry of Education, School of Medicine and Pharmacy, \\ Ocean University of China, Qingdao 266003, China; fantasydxf@163.com (X.D.); \\ wuguanzhao09@hotmail.com (G.W.); zyxlljn@163.com (Y.Z.); xiaominzhang91@163.com (X.Z.); \\ yinruijuan@ouc.edu.cn (R.Y.); jiangtao@ouc.edu.cn (T.J.) \\ 2 Open Studio for Druggability Research of Marine Natural Products, Laboratory for Marine Drugs and \\ Bioproducts, Qingdao National Laboratory for Marine Science and Technology, Qingdao 266237, China \\ * Correspondence: qixin_ouc@ouc.edu.cn (X.Q.); lijing_ouc@ouc.edu.cn (J.L.) \\ + These authors contributed equally to this work.
}

Received: 24 September 2020; Accepted: 9 November 2020; Published: 11 November 2020

\begin{abstract}
A novel camptothecin analogue, (20S)-10,11-methylenedioxy-camptothecin (FL118), has been proven to show significant antitumor efficacy for a wide variety of solid tumors. However, the further development of FL118 is severely hindered due to its extremely poor water solubility and adverse side effects. Here, two series of novel 20-substituted (20S)-10,11-methylenedioxycamptothecin coupled with 5-substituted uracils and other heterocyclic rings through glycine were synthesized. All the derivatives showed superior cytotoxic activities in vitro with $\mathrm{IC}_{50}$ values in the nanomolar range. Among them, 12e displayed higher cytotoxic activities in several cancer cell lines with better water solubility than FL118. Our results further showed that, like FL118, 12e inhibited cell proliferation resulting from cell cycle arrest and apoptosis by blocking the anti-apoptotic gene transcription of survivin, Mcl-1, Bcl-2, and XIAP in both A549 cells and NCI-H446 cells. Furthermore, 12e did not show any inhibitory activity on Topo I, which is involved in hematopoietic toxicity. In vivo, 12e showed similar antitumor efficacy to FL118 but lower toxicity. Our findings indicate that 12e is a promising therapeutic agent for cancer treatment, and the core structure of FL118 represents a promising platform to generate novel FL118-based antitumor drugs.
\end{abstract}

Keywords: Camptothecin derivatives; FL118; 12e; anticancer agent; molecular design

\section{Introduction}

In recent years, the incidence of malignant tumors has become a widespread public health concern. Every year, more than 10 million new cancer cases and nearly seven million deaths are reported worldwide [1]. Chemotherapy is one of the most widely used modalities for cancer treatment, with over one hundred clinically approved drugs available [2]. Among them, camptothecin (CPT) [1] (1, Figure 1), a quinoline alkaloid as an inhibitor of topoisomerase I, is a well-known drug isolated from the Chinese tree Camptotheca by Wall et al. in 1966 [3]. Over the past several decades, many CPT derivatives were synthesized and tested, and its semisynthetic analogues such as topotecan (4, Figure 1) and irinotecan (6, Figure 1) are approved by the USA Food and Drug Administration (FDA) for the treatment of various cancers, such as lung cancer [4-6]. 


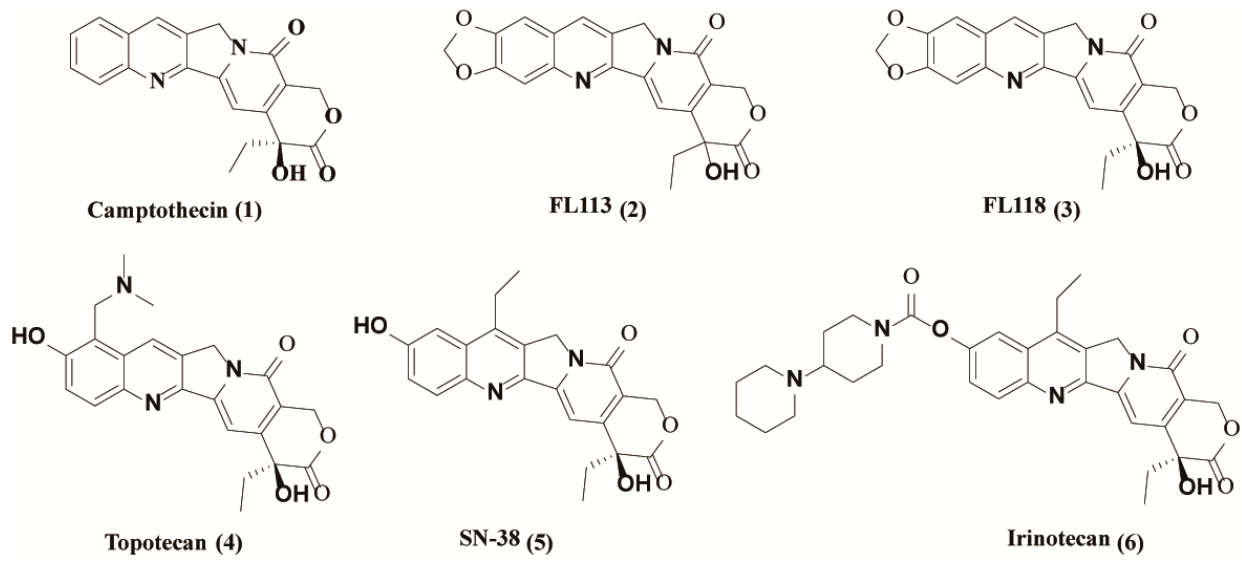

Figure 1. Structures of camptothecin derivatives.

In 2012, (20S)-10,11-methylenedioxy-camptothecin (FL118) (3, Figure 1), with similar structure to SN-38 (active metabolite of irinotecan) (5, Figure 1) and topotecan, was identified by using genetically modified cancer cell models via high throughput screening of chemical compound libraries [7]. Compared to other camptothecin derivatives, FL118 has been proven to possess much higher anticancer activities in many different cancer types both in vitro and in vivo [7]. Studies have demonstrated that the presence of targeted Topo I is not critical for the antitumor activity of FL118, although it has the same core structure with camptothecin [7]. In contrast, the inhibition of Topo I by FL118 may mainly be involved in the side effects of hematopoietic toxicity and possibly diarrhea as well. In fact, FL118 can function as a single anticancer drug that targets multiple different drug-resistant mechanisms. It has been reported that FL118 selectively inhibits gene promoter activities and endogenous expressions of anti-apoptotic proteins, such as survivin, XIAP, cIAP2 and Mcl-1 [8,9], contributing to cell apoptosis induction and antitumor activity [10]. Furthermore, FL118 performs those functions independent of p53 status (wild type, mutant, or null) in cells, and thus it can effectively control cancer with p53 function incapacity, in which most DNA damage drugs (if not all) show a marked lack of efficiency $[7,11]$. Nevertheless, further relevant research of FL118 is severely hindered due to its extremely poor water solubility and adverse side effects [10,12].

It has been revealed that anticancer activity of FL118 is highly dependent on its primary structure and steric configuration [10], suggesting that FL118 may be a promising drug platform for novel derivatives based on its core structure. In early research, it was once believed that the intact six-membered $\alpha$-hydroxy lactone E-ring of CPT was indispensable for antitumor activity, because a free 20-hydroxy group favors lactone ring opening by forming intra-molecular hydrogen bonds (H-bonds), which was the main cause of failure and side effects of camptothecin [13]. However, further investigations demonstrated that modification of the free hydroxyl group at 20-position via an ester bond could be a promising way to improve antitumor efficacy in vitro and in vivo, and to reduce gastrointestinal toxicity [14-19], since esterification of the 20-hydroxy group should disfavor ring opening [20]. In this regard, esterification of 20-hydroxyl group of FL118 could eliminate the intramolecular hydrogen bonding and enhance the steric hindrance of carbonyl group of E-ring. A series of results, such as 20(S)-O-acyl esters [21], 20(S)-O-carbonate linked tripeptide conjugates [22], 20(S)-O-linked glycoconjugates [23], and 20(S)-sulfonylamidine derivatives [18,19], have proved the importance of esterified 1-derivatives as potential anticancer agents. Esterification of the 20-hydroxyl group of 1 can also function as prodrugs to release the CPTs in vivo, and enhance solubility, plasma stability, and pharmacokinetic character of CPTs [20]. Given these considerations, we designed a series of novel 5-substituted uracil and heterocycles esters of FL118 and evaluated their in vitro and in vivo antitumor activity. Results showed that these FL118 derivatives displayed impressive antitumor effects in vitro. More importantly, compound 12e showed high antitumor efficacy in both NCI-H446 and A549 xenograft mouse model without apparent toxicity, which is in line with our research expectation. 
Mechanically, 12e was revealed to have similar molecular mechanism to FL118 via inhibiting the transcription and expression of multiple anti-apoptotic proteins rather than Topo I activity.

\section{Results}

\subsection{Chemistry}

The chemical reactivity of 20-hydroxy group of FL118 is much lower, because this 20-hydroxy group is a tertiary alcohol with strong steric hindrance. Esterification of this hydroxy group under standard conditions is the easiest method for masking it. Therefore, we prepared prodrugs of FL118 as ester derivatives. The synthesis of FL118 was accomplished using a Friedlander condensation according to published procedures [10]. The synthetic routes to target compounds (11a-11c and 12a-12f) were outlined in Scheme 1. Briefly, the 20-hydroxy group of FL118 was converted to N-Boc protected amino esters (7) using a combination of DIC (N, $\mathrm{N}^{\prime}$-diisopropyl carbodiimide) and DMAP (4-dimethylaminopyridine) in a 95\% yield. Subsequently, compound 7 was treated with trifluoroacetic acid in dichloromethane to afford the desired amine intermediates 8 in $2 \mathrm{~h}$. Compound 9 was reacted with bromoacetic acid for $5 \mathrm{~h}$ to generate a carboxylic group. Condensation of the intermediates 8 with the uracil fragments by DMAP and DIC, afforded the hybrids compounds $11 \mathrm{a}-11 \mathrm{c}$ in $74 \%$ to $79 \%$ yields, respectively. In addition, a wide range of heterocyclic components containing pyrrole, piperidine, and substituent piperazine were all efficiently coupled with intermediates 8 , which was first reacted with CDI ( $\mathrm{N}, \mathrm{N}^{\prime}$-Carbonyldiimidazole) as the linker, to provide compounds $12 \mathrm{a}-12 \mathrm{f}$ in $36 \%$ to $78 \%$ yields. All newly synthesized compounds were purified by column chromatography and their structures were confirmed by ${ }^{1} \mathrm{H}$ NMR, ${ }^{13} \mathrm{C}$ NMR, and HRMS.

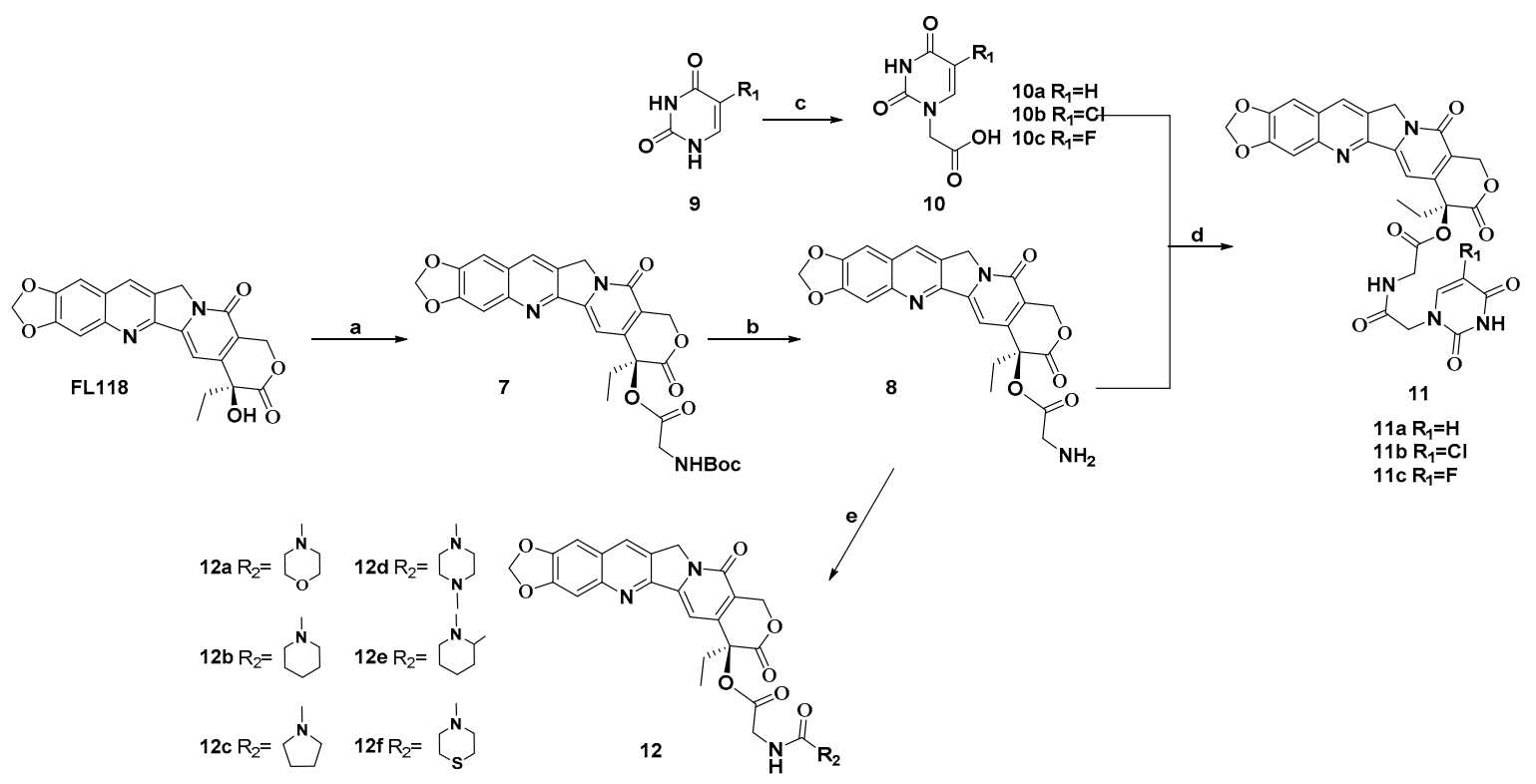

Scheme 1. Synthesis of FL118 derivatives. Reagents and conditions: (a) Boc-Gly-OH, DMAP, DIC, EDCI, DCM, 4 h, 95\%; (b) $\mathrm{CF}_{3} \mathrm{COOH}, \mathrm{CH}_{2} \mathrm{Cl}_{2}, 2$ h, 95\%; (c) $\mathrm{BrCH}_{2} \mathrm{COOH}, \mathrm{KOH}, \mathrm{H}_{2} \mathrm{O}, 60{ }^{\circ} \mathrm{C}, 7 \mathrm{~h}$, 45-56\%; (d) 5'-substituted uracil 1'(N)-acetic acid, DMAP, DIC, DCM, 8 h, 74-79\%; (e) CDI, appropriate $2^{\circ}$ amine, $\mathrm{Et}_{3} \mathrm{~N}, \mathrm{DCM}, 0{ }^{\circ} \mathrm{C}, 8 \mathrm{~h}, 36-78 \%$.

\subsection{2e Inhibits the Proliferation of Various Tumor Cells}

The proliferation inhibitory activities of these synthesized compounds cells were assessed by SRB assay. All the compounds displayed strong cytotoxicity on human non-small cell lung cancer cells A549 with wild type p53, the $\mathrm{IC}_{50}$ values were between 1.37-38.71 nM after $72 \mathrm{~h}$ treatment (Figure 2A). Noteworthily, 12e exhibited strongest cytotoxic activity with 10.28-fold potential than FL118. Hence, 
12e was selected for further studies. Furthermore, 12e was found to have better water solubility than FL118.

A.
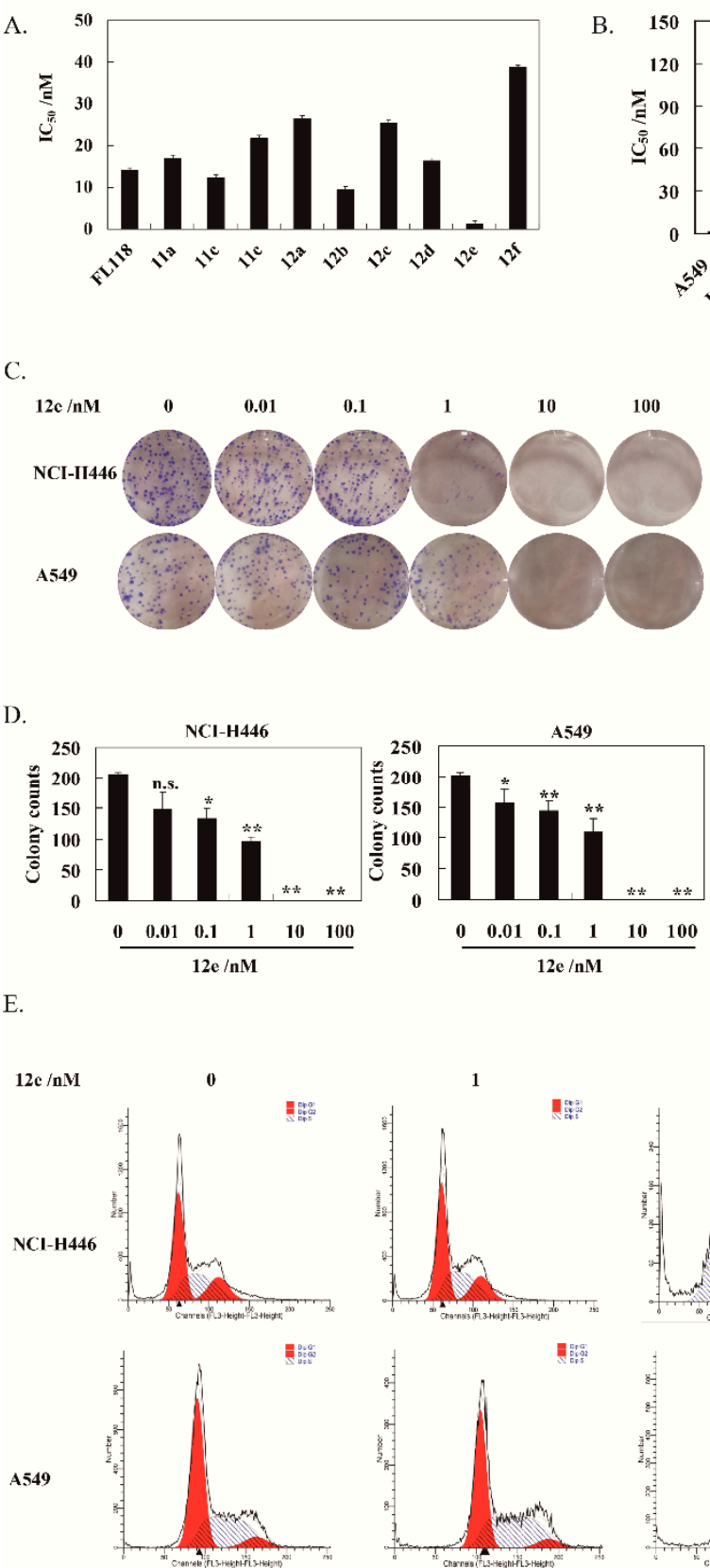

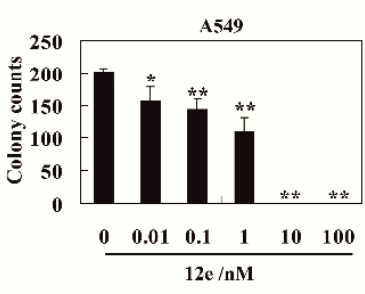

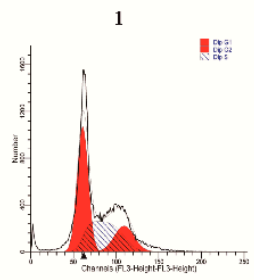

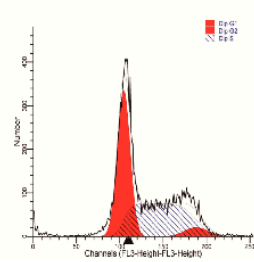

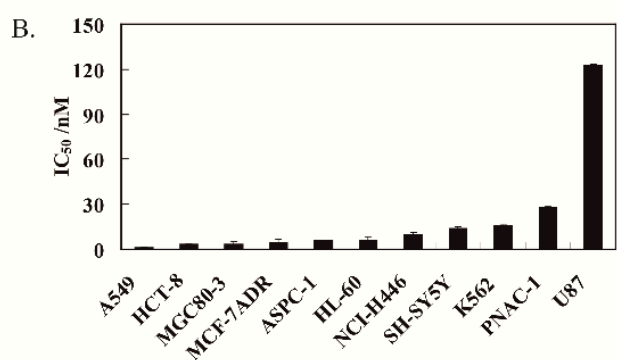

F.
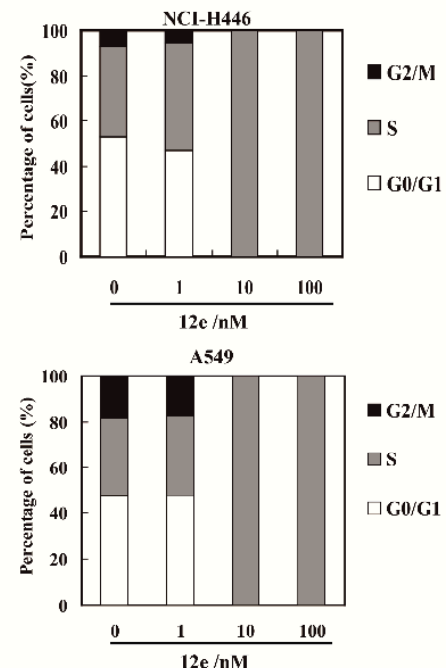

100
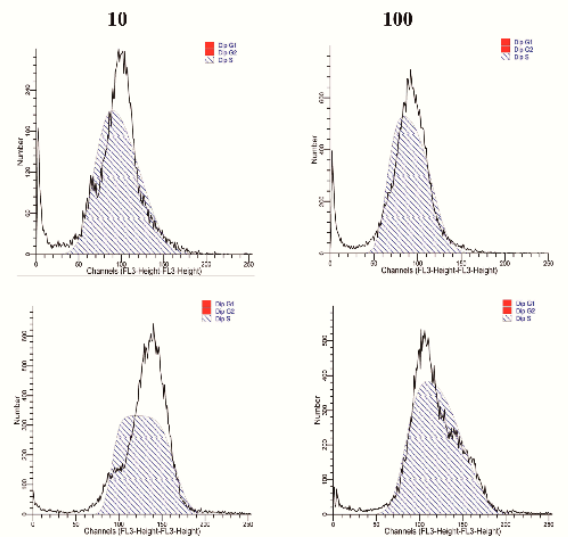

Figure 2. 12e inhibits lung cancer cell growth. (A) A549 cells were treated with various concentrations of synthesized compounds for $72 \mathrm{~h}$. Cell proliferation was determined using SRB assay. (B) Various cancer cells were treated with indicated concentrations of $12 \mathrm{e}$ for $72 \mathrm{~h}$. Cell proliferation was determined using SRB assay. The data are presented as means \pm SD from three independent experiments. (C) 12e inhibits the colony formation. Cells were treated with $12 \mathrm{e}(0.01-100 \mathrm{nM})$ for 14 days, and stained with Giemsa. Then colonies were photographed and counted. (D) Quantification of the number of colonies. Colonies consisting of $\geq 50$ cells were scored. Data are presented as means \pm SD from three independent experiments. ${ }^{*} p<0.05,{ }^{* *} p<0.01$ vs. control. (E) 12e affected cell cycle distribution. Cells were treated with $12 \mathrm{e}(0.01-100 \mathrm{nM})$ for $24 \mathrm{~h}$, then were collected, and stained by PI. The DNA content of cells was determined with the MoFlo XDP flow cytometry system. (F) Histograms show the percentage of cells in $\mathrm{G}_{0} / \mathrm{G}_{1}, \mathrm{G}_{2} / \mathrm{M}$, and $S$ phase after treatment with $12 \mathrm{e}$. 
The cytotoxicity of $12 \mathrm{e}$ on various human cancer cells is summarized in Figure 2B. It was demonstrated that $12 \mathrm{e}$ displayed strong inhibitory activity on these selected cancer cells with $\mathrm{IC}_{50}$ values in the range of 1.37-122.48 $\mathrm{nM}$ after $72 \mathrm{~h}$ of treatment. Among these cancer cells, A549 cells were most sensitive to $12 \mathrm{e}$ with $\mathrm{IC}_{50}$ value at $1.37 \mathrm{nM}$. Thus, A549 cells were used to further explore the anticancer effect and mechanism of 12e in the following research. Given that there is no new drug for small cell lung cancer nearly 30 years [24], the NCI-H446, a human small cell lung cancer line with mutant p53, was also chosen in our research. The $\mathrm{IC}_{50}$ value of $12 \mathrm{e}$ on NCI-H446 was $9.48 \mathrm{nM}$, which was very potent compared to most compounds reported.

Plate clone formation assay is the gold standard for measuring the cytotoxicity of compounds on cancer cells in vitro [25]. Accordingly, 12e showed significant inhibition on the colony-forming abilities of A549 and NCI-H446 cells in a dose-dependent manner (Figure 2C,D). Compared to the control group, the inhibition rates of $12 \mathrm{e}(0.01-1 \mathrm{nM})$ after 14 days of treatment were $22.02 \%, 28.81 \%$, and $45.20 \%$ in NCI-H446 cells, $27.80 \%, 34.88 \%$, and $53.41 \%$ in A549 cells, respectively. When the concentration of $12 \mathrm{e}$ was more than $10 \mathrm{nM}$, the colony-forming was inhibited thoroughly both in A549 and NCI-H446 cells. In order to explore whether the cell cycle arrest contributes to 12e-induced proliferation inhibition, we further analyzed the cell cycle distribution and found that 12e induced S phase arrest in A549 cells and NCI-H446 cells (Figure 2E). In the control group, the cells in S phase represented $33.86 \%$ (NCI-H446) and 39.82\% (A549), and it increased to 34.95\% and $47.56 \%$.in the presence of $1 \mathrm{nM} 12 \mathrm{e}$. While in the presence of 10 and $100 \mathrm{nM} 12 \mathrm{e}$, the cells in S phase rose to $100 \%$ (Figure 2F). These results indicate that 12e suppresses the proliferation of lung cancer cells by arresting the cell cycle in the $S$ phase, which is similar to effect of FL118 on the cell cycle [26,27].

\subsection{2e Induces Cell Apoptosis of A549 Cells and NCI-H446 Cells}

Next, we determine whether $S$ phase arrest induced by 12e resulted in cell apoptosis. In apoptosis, the nucleus undergoes a series of changes including segregation of nucleoli and condensation of chromatin [28]. The nuclear morphology was evaluated after Hoechst 33342 staining. As shown in Figure $3 \mathrm{~A}$, the number of cell nuclei that exhibited brighter blue fluorescence, shrinkage, or DNA fragmentation (shown by arrows) was increased significantly after exposure to 12e in A549 cells and NCI-H446 cells dose-dependently. Furthermore, the levels of $\gamma$-H2AX, an essential marker of DNA double-strand breaks, was increased significantly in a dose-dependent manner (Figure 3B), suggesting that 12e induced DNA double-strand breaks, which was consistent with the influence of FL118 on DNA strand [29].

Cysteinyl aspartate specific proteinase-9 (caspase-9) is the apical caspases in the intrinsic apoptosis pathways, and cysteinyl aspartate specific proteinase-3 (caspase-3) is considered to be the most important component to the effectors caspases. The cleaving and activation of the caspase-9/caspase-3 is a hallmark of the intrinsic apoptosis [30]. In addition, the poly-adenosine diphosphate-ribose polymerase (PARP) protein is a substrate of caspase-3. Cleaved PARP seems to be an early marker of apoptosis in cells. Bax, a member of the Bcl-2 family, can promote apoptosis mediated by mitochondria. As shown in Figure 3B, we observed obvious increases of cleaved caspase-9, cleaved caspase-3, cleaved PARP, and pro-apoptotic protein bax in the presence of 12e. Meanwhile, the levels of caspase-8, an important component of the death signal receptor pathway of apoptosis [31], had no change after exposure to 12e treatment. Taken together, 12e induces A549 and NCI-H446 cell apoptosis involved in mitochondrial pathway rather than death receptor pathway.

In order to quantify the extent of apoptosis, flow cytometry analysis was performed to detect 12e-induced apoptosis rates by Annexin V-FITC and PI staining. Annexin V-FITC and PI double staining can distinguish apoptotic cells, necrotic cells as well as normal cells. The specific binding of phosphatidylserine exposed on the cell surfaces undergoing apoptosis with Annexin V can be used to detect apoptotic cells. The late apoptotic cells and necrotic cells were assessed by propidium iodide (PI) staining [32]. As shown in Figure 3C, after treatment by 12e $(0,1,10$, and $100 \mathrm{nM})$ for $24 \mathrm{~h}$, the rates of early and late apoptosis (AV+/PI-) were $6.76 \%, 12.57 \%, 18.52 \%$, and $20.32 \%$ in NCI-H446 
cells, and $6.84 \%, 12.55 \%, 15.61 \%$, and $24.17 \%$ in A549 cells, respectively. These results support that $12 \mathrm{e}$ induces cell apoptosis.

A.
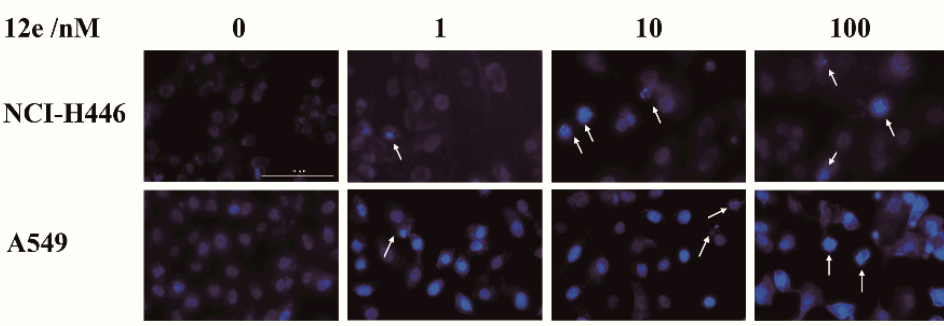

B.

$12 \mathrm{e} / \mathrm{nM}$

NCI-H446

A549

Cleaved PARP

caspase-8

Cleaved caspase-9

Cleaved caspase-3
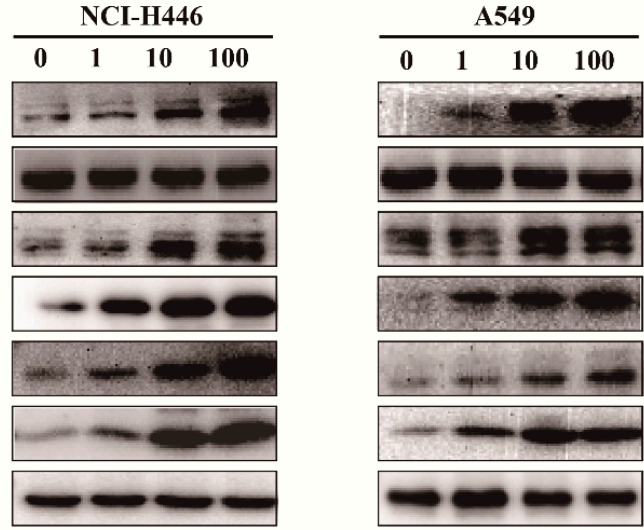

C. $12 \mathrm{e} / \mathrm{nM}$
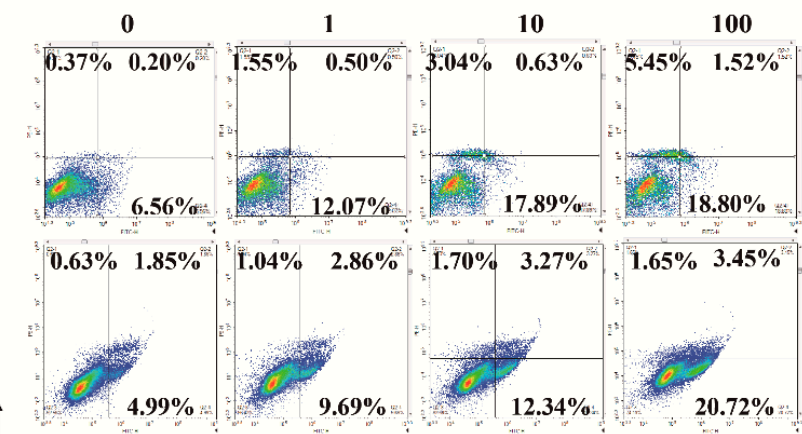

PI

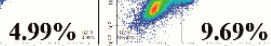

$9.69 \%$

$\underset{\mathrm{Annexin} \mathbf{V}}{\longrightarrow}$

D.
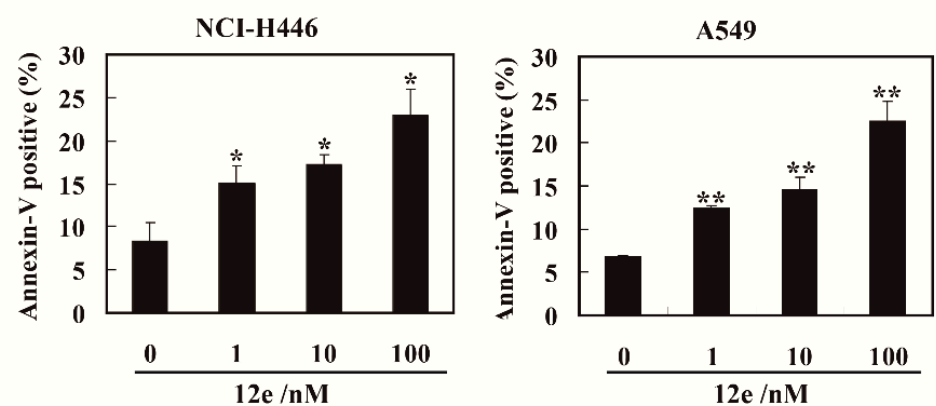

Figure 3. 12e promotes apoptosis of lung cancer cell lines. (A) NCI-H446 and A549 cells were treated with $12 \mathrm{e}(0-100 \mathrm{nM})$ for $24 \mathrm{~h}$, then stained with Hoechst 33342 , the photos were taken using microscopy (magnification, 200x). The brighter blue fluorescence (indicted arrows), show apoptotic cells. (B) Western blotting analysis of the expression level of apoptosis-related proteins in indicated cells after treated with 12e. $\beta$-tubulin was chosen as the internal control. (C) Apoptosis rate of cancer cells induced by 12e. Cells were treated with indicated concentrations of $12 \mathrm{e}$ for $24 \mathrm{~h}$, then stained with Annexin V-FITC/PI, and determined by flow cytometry. (D) Quantification of the Annexin-V positive cells, ${ }^{*} p<0.05,{ }^{* *} p<0.01$ vs. control. 


\subsection{2e does not Impair Cell Proliferation Signaling in A549 Cells and NCI-H446 Cells}

Cell proliferations, apoptosis and differentiations are regulated by cell signal transduction pathway. In various cancer cells, stat 3 , AKT and erk1/2 were abnormally activated, which are molecules in three main signaling pathway, relating to the cell proliferation and survive [33-35]. To investigate which cell signaling transduction pathway was involved in 12e-induced cell apoptosis, we investigated the expressions and activations of stat3, AKT and erk1/2 by western blot assay. As shown in Figure 4, after treatment with 1,10 , and $100 \mathrm{nM} 12 \mathrm{e}$ for $24 \mathrm{~h}$, the levels of stat3, AKT, and erk1/2 had no significant change, and the phosphorylation levels of stat3, AKT, and erk $1 / 2$ were not appreciably decreased on NCI-H446 and A549 cells. These results indicate that 12e-induced apoptosis is probably not associated with the inactivation of cell proliferation upstream signaling.

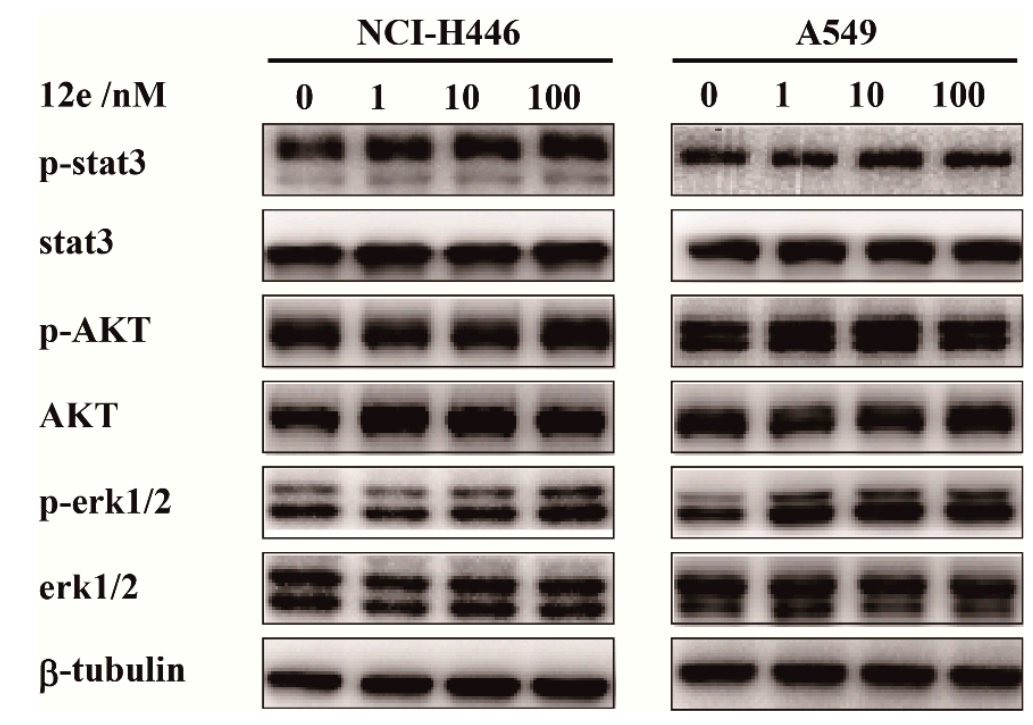

Figure 4. 12e does not impair cell proliferation upstream signaling in lung cancer cell lines. NCI-H446 and A549 cells were treated with $12 \mathrm{e}(0-100 \mathrm{nM})$ for $24 \mathrm{~h}$, the levels of proliferation-related proteins were detected by western blotting. $\beta$-tubulin served as the loading control.

\subsection{2e Reduces the Transcription and Expression of Multiple Anti-Apoptotic Proteins}

The IAP family and Bcl-2 family proteins play important roles in suppressing apoptosis of cells [36]. It was reported that FL118 inhibited the transcriptions and expressions of survivin, XIAP and Mcl-1 $[8,9]$. We then tested whether 12e affected the expression levels of these anti-apoptotic proteins. After treatment with 1 to $100 \mathrm{nM}$ of 12e for $24 \mathrm{~h}$, the protein levels of survivin, Bcl-2, Mcl-1, and XIAP were down-regulated both in A549 and NCI-H446 cells in a dose-dependent manner (Figure 5A). Accordingly, the RT-PCR assay showed that the mRNA levels of survivin, Bcl-2, Mcl-1 and XIAP were decreased significantly (Figure 5B). All these data suggest that 12e inhibits the genetic transcription of multiple anti-apoptotic proteins and their subsequent expression. Early studies have demonstrated that camptothecin (CPT) inhibits the synthesis of DNA and protein, due to inhibition of DNA topoisomerase I (Topo I) activity [37]. Previous studies showed that the inhibition of Topo I activity by FL118 did not play a major role in its antitumor activity $[7,10]$. To determine whether 12e inhibited DNA Topo I activity, a Topo I -Mediated Relaxation of pBR322 DNA Assay was performed. The pBR322 DNA was presented as supercoiled state (SC) without treatment of Topo I, and relaxed state (RLX) with the treatment of Topo I. After co-treated with CPT, the relaxation activity of Topo I was inhibited and SC DNA was reversely increased distinctly, while the pBR322 DNA was still presented as RLX after co-treated with FL118, or 12e (Figure 5C). Intriguingly, FL118 exhibited a bit weak inhibitory activity on Topo I than 12e, as 12e did not show any inhibitory activity on it. Meanwhile, we observed that compounds $12 \mathrm{a}$ and $12 \mathrm{c}$ showed no inhibitory activity on Topo I. These results suggest that 12e inhibits 
transcriptions and expressions of multiple anti-apoptotic proteins, thereby inducing cell apoptosis of A549 and NCI-H446 cells independent of Topo I activity.

A.

\begin{tabular}{|c|c|c|c|}
\hline \multirow{3}{*}{$\begin{array}{l}12 \mathrm{e} / \mathrm{nM} \\
\text { survivin }\end{array}$} & \multicolumn{3}{|c|}{ NCI-H446 } \\
\hline & $\begin{array}{ll}0 & 1\end{array}$ & 10 & 100 \\
\hline & 6 & - & $\infty$ \\
\hline Bcl-2 & S. & - & $\because$ \\
\hline Mel-1 & 6 & 6 & 6 \\
\hline & $E$ & 3 & 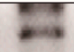 \\
\hline
\end{tabular}

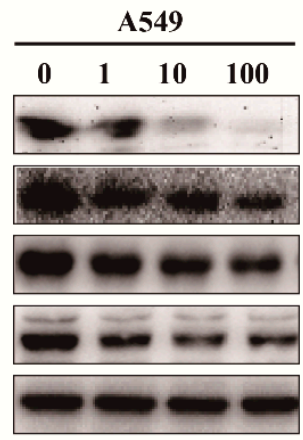

B.

NCI-H446

A549
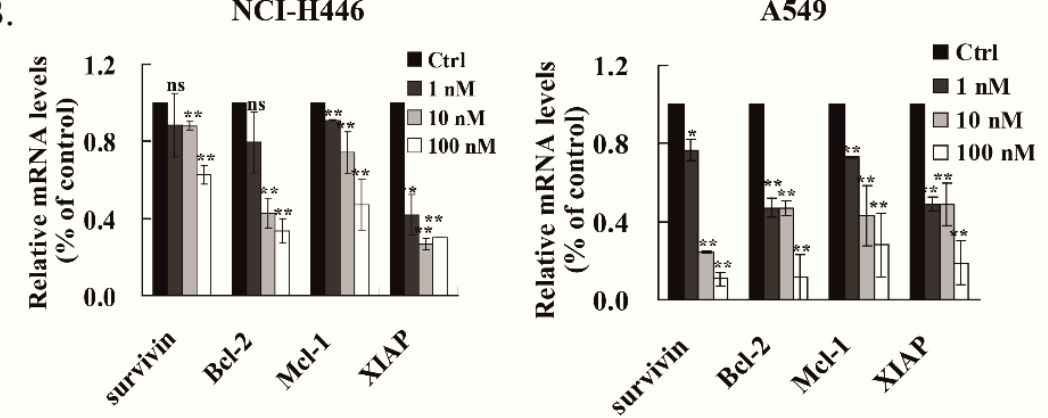

C.

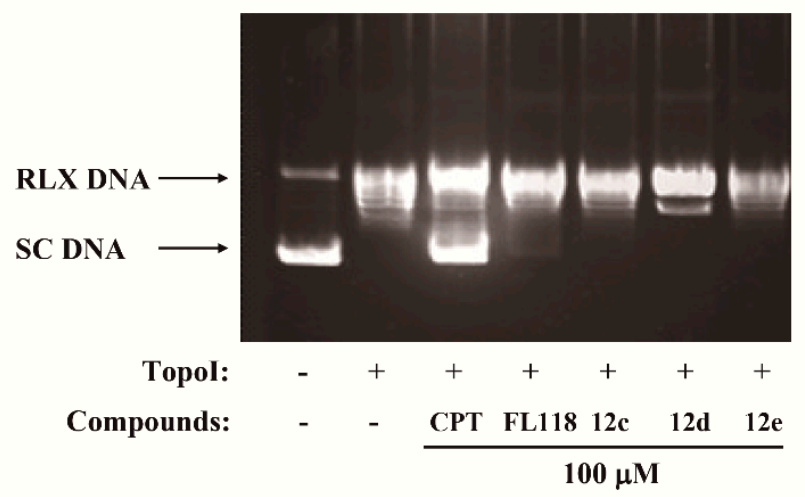

Figure 5. 12e treatment reduces the transcription and expression of multiple anti-apoptotic proteins in lung cancer cell lines. (A) NCI-H446 and A549 cells were treated with 12e (0-100 nM) for $24 \mathrm{~h}$, the expression levels of survivin, Bcl-2, Mcl-1 and XIAP were detected by western blotting. $\beta$-tubulin was chosen as the internal control. (B) Upon exposure to $12 \mathrm{e}(0-100 \mathrm{nM})$ for $24 \mathrm{~h}$, the relative mRNA level of survivin, Bcl-2, Mcl-1 and XIAP in NCI-H446 and A549 cells were determined using RT-PCR technique. ${ }^{*} p<0.05,{ }^{* *} p<0.01$ vs. control. (C) Topo I- Mediated relaxation of pBR322 DNA Assay with or without indicated compounds. The pBR322 DNA was presented as supercoiled (SC) without treatment of Topo I, and relaxed (RLX) with the treatment of Topo I. CPT was used as a positive control.

\subsection{2e Suppresses the Growth of Lung Cancer Cells Xenograft In Vivo}

Next, we studied the in vivo antitumor activity of 12e using animal xenograft models of human A549 and NCI-H446 cancer cells. We compared the antitumor activities of 12e and FL118 at a dose of $10 \mathrm{mg} / \mathrm{kg}$ by intragastric administration once per week. As shown in Figure 6, 12e exhibited a distinct reduction in tumor volume compared to vehicle in A549 and NCI-H446 xenografts with similar antitumor activity to FL118 (Figure 6A,B). The inhibitory rates of 12e and FL118 were $48.8 \%$ and 59.8\% (A549 xenografts), and 70.3\% and 75.4\% (NCI-H446 xenografts) respectively. During the period of 
drug administration, the mice body weights of FL118 group lost obviously both in A549 and NCI-H446 xenograft models compared with control group, while 12e did not induce an obvious loss of mice body weight (Figure 6C,D). The results indicated that 12e has weaker toxicity than FL118. Furthermore, just like FL118 12e down-regulated the expression of survivin, Mcl-1, Bcl-2 and XIAP in A549 and NCI-H446 xenograft tumors (Figure 6E). These findings indicate that 12e suppresses lung cancer growth in vivo through same mechanism as FL118, but with weak toxicity.

A.

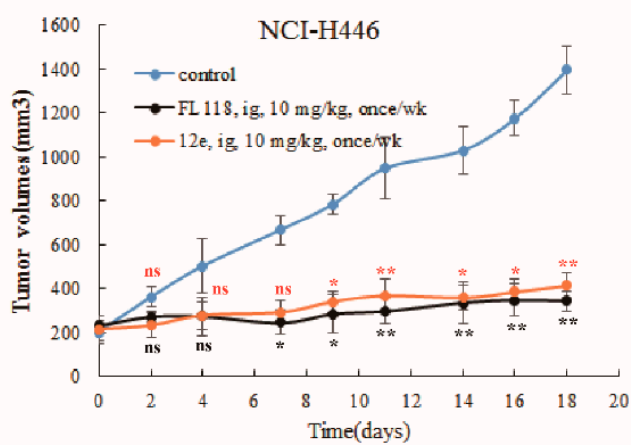

C.

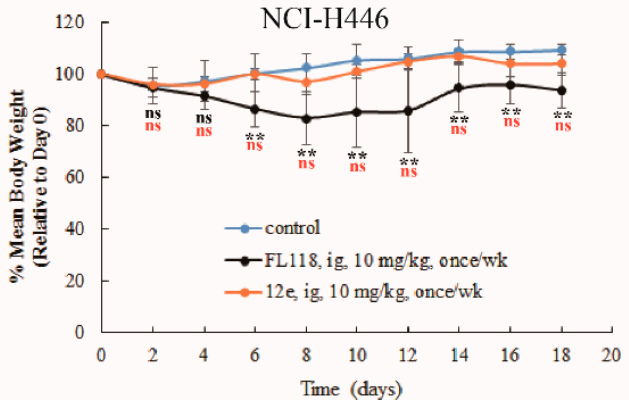

E.

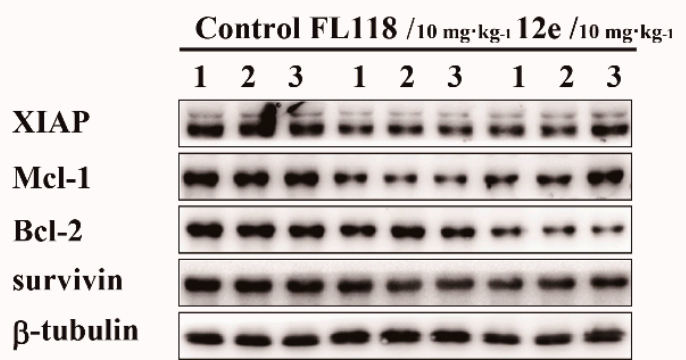

B.

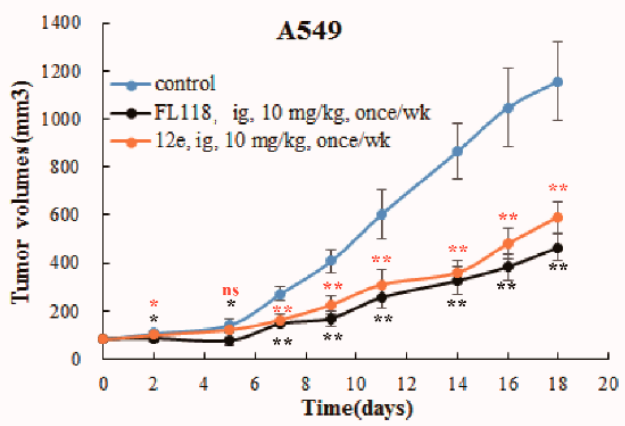

D.

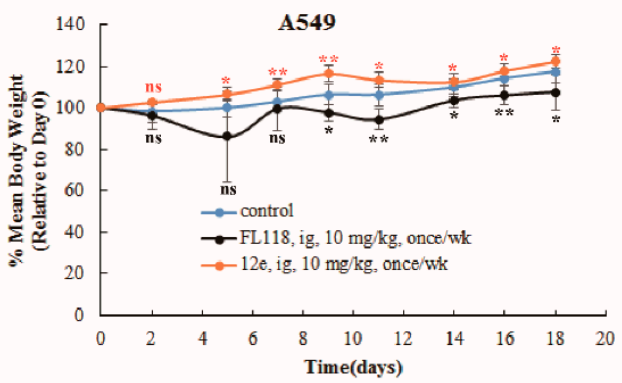

A549

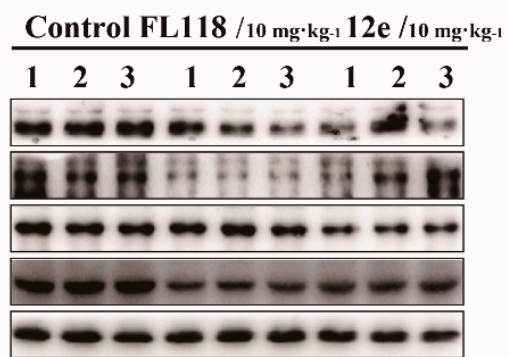

Figure 6. 12e suppresses tumor growth in vivo. A549 or NCI-H446 bearing mice were intragastrically administrated with FL118, 12e or vehicle, and the tumor volumes and body weights of mice were determined. (A) The tumor volumes of A549 xenografts. (B) The tumor volumes of NCI-H446 xenografts. (C) Body weights of A549 bearing mice. (D) Body weights of NCI-H446 bearing mice. (E) Western blotting analyzes the expression levels of survivin, Bcl-2, Mcl-1and XIAP in the excised tumor tissues. $\beta$-tubulin was chosen as the internal control. ${ }^{*} p<0.05,{ }^{* *} p<0.01$ vs. control.

\section{Discussion}

In this study, novel 20-substituted FL118 derivatives coupled with 5-substituted uracils and other heterocyclic rings through glycine were synthesized. All the derivatives showed superior cytotoxic activities in vitro, with $\mathrm{IC}_{50}$ values between $1.37-38.71 \mathrm{nM}$ after $72 \mathrm{~h}$ treatment in A549 cell lines. 
Among them, 12e displayed higher cytotoxic activities on various human cancer cells including A549 and NCI-H446 cells. In addition, 12e was found to have better water solubility and more potential cytotoxic effect than FL118. Cell cycle arrest and apoptosis were the two main causes of growth inhibition [38]. Moreover, 12e suppressed the proliferation of NCI-H446 and A549 cells by arresting the cell cycle at the $S$ phase, which resulted in cell apoptosis. This result is consistent with previous studies that FL118 induced S phase arrest in several types of human cancer cell line $[19,20]$. With Hoechst 33342 staining, western blot and flow cytometry analysis, our data showed that 12e induced apoptosis in NCI-H446 and A549 lung cells via up-regulation of $\gamma \mathrm{H} 2 \mathrm{AX}$ and bax, down-regulation of survivin, Bcl-2, Mcl-1 and XIAP with cleavage and activation of caspase-3, caspase-9, and PARP. PI3K/AKT, JAK/STAT3, and RAS/ERK1/2 signaling pathways contribute to a variety of processes that are critical in mediating many aspects of cellular function including cell growth and survival, abnormalities of these pathways have been reported in many human tumors, and inhibitors against these pathways promote cell apoptosis [39]. However, there is no change in the activations and expressions of AKT, stat 3 and erk $1 / 2$ after 12 e treatment, indicating that 12 e plays a role in the downstream of these signaling pathway related to cell growth and survival. As expected, 12e was verified to inhibit the genetic transcription of multiple anti-apoptotic proteins, which is in line with the report that FL118 binds to similar promoter region of the survivin, Mcl-1, Bcl-2 and XIAP genes, and thereby inhibiting these genes transcription. Moreover, we confirmed that FL118 exhibited weaker inhibitory activity on Topo I than 12e, as 12e did not show any inhibitory activity on Topo I. Inhibition of Topo I by FL118 is predominantly involved in hematopoietic toxicity [25], but not in FL118 antitumor activity, which may be an explanation for the lower toxicity of 12e. Previous studies indicated that FL118 treatment in its oral formulation has a maximum tolerance dose of $10 \mathrm{mg} / \mathrm{kg}$ in human tumor-bearing SCID with the weekly $\times 4$ schedule [19]. Similarly, we found that 12e showed high antitumor efficacy in both NCI-H446 and A549 mouse models at a dose of $10 \mathrm{mg} / \mathrm{kg}$ with the weekly $\times 4$ schedule. More importantly, 12e did not cause apparent toxicity in xenograft mice compared to FL118, which is in line with our original intention of molecular design.

In summary, through esterification of the 20-hydroxy group of FL118 with 5-substituted uracils and $\mathrm{N}$-containing heterocycles via a glycine linker, we successfully obtained a new compound 12e with similar antitumor activity to FL118 while lower toxicity. In addition, mechanism research reveals that 12e inhibits transcriptions and expressions of anti-apoptotic protein survivin, Bcl-2, Mcl-1 and XIAP in line with molecular mechanism of FL118. Our findings indicate that the core structure of FL118 represents a promising platform for the generation of novel FL118 derivatives, which lays the foundation for further antitumor drug development in the future.

\section{Materials and Methods}

\subsection{Chemistry}

\subsubsection{Materials and Methods}

All reagents and solvents were reagent grade or were purified by standard methods before use. Melting points were determined in open capillaries and are uncorrected. ${ }^{1} \mathrm{H}$ and ${ }^{13} \mathrm{C}$ NMR spectra were recorded at $400 \mathrm{MHz}$ and $100 \mathrm{MHz}$ on a Bruker AM-400 spectrometer using TMS as reference (Bruker Daltonics Inc., Billerica, MA, USA). Chemical shifts ( $\delta$ values) and coupling constants ( $J$ values) are given in ppm and $\mathrm{Hz}$, respectively. Anhydrous tetrahydrofuran (THF) was obtained by distillation from sodium-benzophenone ketyl; dry methylene chloride was obtained by distillation from phosphorus pentoxide. All reactions requiring anhydrous conditions were performed under a positive nitrogen flow, and all glassware were oven dried and/or flame dried. Isolation and purification of the compounds were performed by flash column chromatography on silica gel (200-300 mesh) produced by Qingdao Marine Chemical Factory, Qingdao (China). Analytical thin-layer chromatography (TLC) was conducted on Fluka TLC plates (silica gel 60 F254, aluminum foil). 


\subsubsection{Synthesis of FL118}

FL118 was synthesized according to our previous procedures [10], namely in three steps from the commercially available piperonal.

4.1.3. Synthesis of (S)-7-ethyl-8,11-dioxo-7,8,11,13-tetrahydro-10H-[1,3]dioxolo[4,5-g]pyrano[3' $\left.4^{\prime}: 6,7\right]$ indolizino[1,2-b]quinolin-7-yl (tert-butoxycarbonyl)glycinate (7)

FL118 (0.50 mmol), Boc-Gly-OH $(0.60 \mathrm{mmol})$, and DMAP $(1.02 \mathrm{mmol})$ were dissolved in anhydrous DCM $(50 \mathrm{~mL})$ under $\mathrm{N}_{2}$ at $0{ }^{\circ} \mathrm{C}$. DIC $(1.20 \mathrm{mmol})$ was added dropwise into the reaction mixture. The mixture was stirred for $1 \mathrm{~h}$ at $0{ }^{\circ} \mathrm{C}$ and then stirred overnight at room temperature. The mixture was washed with $100 \mathrm{mM} \mathrm{HCl}$ aqueous solution $(3 \times 100 \mathrm{~mL})$, water $(3 \times 100 \mathrm{~mL})$, and saturated brine $(3 \times 100 \mathrm{~mL})$. The organic layer was dried over anhydrous $\mathrm{Na}_{2} \mathrm{SO}_{4}$ and purified by silica gel column chromatography (Acetone/DCM = 1:20 to 10:1, v/v) (95\% yield). mp 241-242 ${ }^{\circ} \mathrm{C}$; HRMS (ESI): calcd for $\mathrm{C}_{28} \mathrm{H}_{27} \mathrm{~N}_{3} \mathrm{O}_{9}$ 550.5360, found 550.1806. ${ }^{1} \mathrm{H}$ NMR (500 MHz, DMSO) $\delta 8.34(\mathrm{~s}, 1 \mathrm{H}), 7.36(\mathrm{~s}, 2 \mathrm{H}), 7.02$ $(\mathrm{d}, J=70.1 \mathrm{~Hz}, 1 \mathrm{H}), 6.24(\mathrm{~s}, 2 \mathrm{H}), 5.45(\mathrm{~s}, 2 \mathrm{H}), 5.08(\mathrm{~d}, J=25.9 \mathrm{~Hz}, 2 \mathrm{H}), 3.87(\mathrm{dd}, J=54.0,17.3 \mathrm{~Hz}, 2 \mathrm{H})$, 2.10 (s, 2H), 1.32 (d, 6H), 0.94 (d, 6H). ${ }^{13} \mathrm{C}$ NMR (125 MHz, DMSO) \& 169.98, 167.64, 157.03, 156.29, $151.82,149.97,149.09,146.81,146.63,145.88,130.60,128.58,125.99,118.23,104.79,103.46,103.07,95.30$, $79.08,76.70,66.61,50.46,42.34,41.06,30.69,28.20,23.63,7.93$.

4.1.4. Synthesis of (S)-7-ethyl-8,11-dioxo-7,8,11,13-tetrahydro-10H-[1,3]dioxolo[4,5-g]pyrano[3' $\left.4^{\prime}: 6,7\right]$ indolizino[1,2-b]quinolin-7-yl glycinate (8)

Compound $7(0.36 \mathrm{mmol})$ was dissolved in TFA $(20 \mathrm{~mL})$, and the solution was stirred for $1 \mathrm{~h}$ at room temperature. The solution was evaporated and purified by silica gel column chromatography (Acetone/DCM $=1: 10$ to $1: 1, v / v)\left(95 \%\right.$ yield). $\mathrm{mp}>250{ }^{\circ} \mathrm{C}$; HRMS (ESI): calcd for $\mathrm{C}_{23} \mathrm{H}_{19} \mathrm{~N}_{3} \mathrm{O}_{7} 450.4190$, found 450.1288. ${ }^{1} \mathrm{H}$ NMR (500 MHz, DMSO) $\delta 8.44(\mathrm{~s}, 1 \mathrm{H}), 7.45(\mathrm{~s}, 1 \mathrm{H}), 7.40(\mathrm{~s}, 1 \mathrm{H}), 7.16(\mathrm{~s}, 1 \mathrm{H}), 6.25$ $(\mathrm{s}, 2 \mathrm{H}), 5.48(\mathrm{~d}, J=16.5 \mathrm{~Hz}, 2 \mathrm{H}), 5.16(\mathrm{~d}, J=20.9 \mathrm{~Hz}, 2 \mathrm{H}), 4.26(\mathrm{~d}, J=17.9 \mathrm{~Hz}, 1 \mathrm{H}), 4.06(\mathrm{~d}, J=17.9 \mathrm{~Hz}$, 1H), $2.21-2.09$ (m, 2H), $0.98-0.89$ (m, 3H). ${ }^{13} \mathrm{C}$ NMR (125 MHz, DMSO) $\delta 167.34,167.15,156.99$, $151.97,149.97,149.22,146.89,146.86,145.20,130.85,128.80,126.18,118.33,104.77,103.62,103.12,95.17$, $78.01,66.75,50.61,30.57,23.63,7.93$.

\subsubsection{General Procedure for the Synthesis of Compounds 11a-11c}

Compound 8 (0.13 mmol), 5-substituted uracil acid 10a-10c (1.1 mmol), and DMAP (0.20 mmol) were dissolved in anhydrous DCM $(20 \mathrm{~mL})$ at $0{ }^{\circ} \mathrm{C}$. DIC $(0.20 \mathrm{mmol})$ was added dropwise into the reaction mixture. The mixture was stirred for $1 \mathrm{~h}$ at $0{ }^{\circ} \mathrm{C}$ and then stirred for overnight at room temperature. The mixture was washed with $100 \mathrm{mM} \mathrm{HCl}$ aqueous solution $(3 \times 100 \mathrm{~mL})$, water $(3 \times 100 \mathrm{~mL})$, and saturated brine $(3 \times 100 \mathrm{~mL})$. The organic layer was dried over anhydrous $\mathrm{Na}_{2} \mathrm{SO}_{4}$ and purified by silica gel column chromatography (Acetone/DCM $=1: 20$ to 10:1, v/v) to yield the desired compound, 11a-11c, respectively.

(S)-7-ethyl-8,11-dioxo-7,8,11,13-tetrahydro-10H-[1,3]dioxolo[4,5-g]pyrano[3' $\left.4^{\prime}: 6,7\right]$ indolizino[1,2-b]quinolin-7-yl (2-(2,4-dioxo-3,4-dihydropyrimidin-1(2H)-yl)acetyl)glycinate (11a)

The general synthetic method described above afforded compound 11a as a yellow solid (77\%). $\mathrm{mp}>250{ }^{\circ} \mathrm{C}$; HRMS (ESI): calcd for $\mathrm{C}_{29} \mathrm{H}_{23} \mathrm{~N}_{5} \mathrm{O}_{10}$ 602.5280, found 602.1506. ${ }^{1} \mathrm{H}$ NMR (500 MHz, DMSO) $\delta 11.21(\mathrm{~s}, 1 \mathrm{H}), 8.71(\mathrm{~s}, 1 \mathrm{H}), 8.38(\mathrm{~s}, 1 \mathrm{H}), 7.46(\mathrm{~d}, J=31.5 \mathrm{~Hz}, 3 \mathrm{H}), 7.01(\mathrm{~s}, 1 \mathrm{H}), 6.26(\mathrm{~s}, 2 \mathrm{H}), 5.46$ $(\mathrm{s}, 3 \mathrm{H}), 5.11(\mathrm{~s}, 2 \mathrm{H}), 4.35(\mathrm{~s}, 2 \mathrm{H}), 4.22(\mathrm{~s}, 1 \mathrm{H}), 4.09(\mathrm{~s}, 1 \mathrm{H}), 2.15(\mathrm{~s}, 2 \mathrm{H}), 0.89(\mathrm{~s}, 3 \mathrm{H}) .{ }^{13} \mathrm{C} \mathrm{NMR}(125 \mathrm{MHz}$, DMSO) $\delta 169.16,167.91,167.52,164.22,156.91,151.84,151.37,150.10,149.12,146.86,145.38,130.58$, $128.75,127.84,126.08,118.48,114.29,105.07,103.50,103.05,101.07,94.70,76.84,66.79,50.51,49.67$, $30.86,7.97$. 
(S)-7-ethyl-8,11-dioxo-7,8,11,13-tetrahydro-10H-[1,3]dioxolo[4,5-g]pyrano[3' $\left.4^{\prime}: 6,7\right]$ indolizino[1,2-b] quinolin-7-yl (2-(5-chloro-2,4-dioxo-3,4-dihydropyrimidin-1(2H)-yl)acetyl)glycinate (11b)

The general synthetic method described above afforded compound $\mathbf{1 1 b}$ as a yellow solid (79\%), mp 242-243 ${ }^{\circ} \mathrm{C}$; HRMS (ESI): calcd for $\mathrm{C}_{29} \mathrm{H}_{22} \mathrm{ClN}_{5} \mathrm{O}_{10} 636.9700$, found 636.1151. ${ }^{1} \mathrm{H}$ NMR $(500 \mathrm{MHz}$, DMSO) $\delta 11.79(\mathrm{~s}, 1 \mathrm{H}), 8.74(\mathrm{~s}, 1 \mathrm{H}), 8.38(\mathrm{~s}, 1 \mathrm{H}), 8.03(\mathrm{~s}, 1 \mathrm{H}), 7.42(\mathrm{~s}, 2 \mathrm{H}), 7.01(\mathrm{~s}, 1 \mathrm{H}), 6.26(\mathrm{~s}, 2 \mathrm{H}), 5.46$ $(\mathrm{s}, 2 \mathrm{H}), 5.11(\mathrm{~s}, 2 \mathrm{H}), 4.36(\mathrm{~s}, 2 \mathrm{H}), 4.24(\mathrm{dd}, J=18.3,5.5 \mathrm{~Hz}, 1 \mathrm{H}), 4.09(\mathrm{dd}, J=17.9,5.3 \mathrm{~Hz}, 1 \mathrm{H}), 2.19-2.09$ $(\mathrm{m}, 2 \mathrm{H}), 0.90(t, J=7.1 \mathrm{~Hz}, 3 \mathrm{H}) .{ }^{13} \mathrm{C}$ NMR $(125 \mathrm{MHz}, \mathrm{DMSO}) \delta 169.11,167.61,167.51,159.95,156.91$, $151.84,150.51,150.09,149.12,146.90,146.86,145.39,144.01,130.55,128.74,126.07,118.45,106.38,105.08$, $103.48,103.04,94.70,76.86,66.79,50.50,49.99,40.72,30.85,7.97$.

(S)-7-ethyl-8,11-dioxo-7,8,11,13-tetrahydro-10H-[1,3]dioxolo[4,5-g]pyrano[3' $4^{\prime}$ :6,7]indolizino[1,2-b] quinolin-7-yl (2-(5-fluoro-2,4-dioxo-3,4-dihydropyrimidin-1(2H)-yl)acetyl)glycinate (11c)

The general synthetic method described above afforded compound $11 \mathrm{c}$ as a yellow solid (74\%), mp 242-243 ${ }^{\circ} \mathrm{C}$; HRMS (ESI): calcd for $\mathrm{C}_{29} \mathrm{H}_{22} \mathrm{FN}_{5} \mathrm{O}_{10} 620.5184$, found $620.1409 .{ }^{1} \mathrm{H}$ NMR $(500 \mathrm{MHz}$, DMSO) $\delta 8.73(\mathrm{~s}, 1 \mathrm{H}), 8.37(\mathrm{~s}, 1 \mathrm{H}), 7.97(\mathrm{~d}, J=6.4 \mathrm{~Hz}, 1 \mathrm{H}), 7.41(\mathrm{~s}, 2 \mathrm{H}), 7.01(\mathrm{~s}, 1 \mathrm{H}), 6.26(\mathrm{~s}, 2 \mathrm{H}), 5.46$ $(\mathrm{s}, 2 \mathrm{H}), 5.09(\mathrm{~s}, 2 \mathrm{H}), 4.29(\mathrm{~d}, J=18.1 \mathrm{~Hz}, 2 \mathrm{H}), 4.26-4.17(\mathrm{~m}, 1 \mathrm{H}), 4.11-4.02(\mathrm{~m}, 1 \mathrm{H}), 2.19-2.07(\mathrm{~m}, 2 \mathrm{H})$, $0.90(t, J=6.8 \mathrm{~Hz}, 3 \mathrm{H}) .{ }^{13} \mathrm{C}$ NMR $(125 \mathrm{MHz}, \mathrm{DMSO}) \delta 169.12,167.68,167.51,156.91,151.84,150.07$, $150.04,149.11,146.90,146.84,145.40,140.65,131.35,131.07,130.54,128.70,126.05,118.46,105.04,103.47$, $103.05,94.71,76.85,66.79,50.48,49.86,40.72,30.86,7.97$.

\subsubsection{General Procedure for the Synthesis of Compounds 12a-12f}

Compound $8(0.11 \mathrm{mmol})$ and Triethylamine $(0.02 \mathrm{mmol})$ was dissolved in anhydrous DCM $(50 \mathrm{~mL})$ under $\mathrm{N}_{2}$ at $0{ }^{\circ} \mathrm{C}$. Then CDI $(0.14 \mathrm{mmol})$ in anhydrous DCM $(10 \mathrm{~mL})$ was then added. After stirring at room temperature for $1 \mathrm{~h}$, various heterocycles $(0.154 \mathrm{mmol})$ were added into the solution, and the reaction mixture was stirred overnight at room temperature. The mixture was washed with water $(3 \times 100 \mathrm{~mL})$, and saturated brine $(3 \times 100 \mathrm{~mL})$. The organic layer was dried over anhydrous $\mathrm{Na}_{2} \mathrm{SO}_{4}$ and purified by silica gel column chromatography (Acetone/DCM $=1: 8$ to $5: 1, v / v$ ) to yield the desired compound, 12a-12f, respectively.

(S)-7-ethyl-8,11-dioxo-7,8,11,13-tetrahydro-10H-[1,3]dioxolo[4,5-g]pyrano[3' $\left.3^{\prime} 4^{\prime}: 6,7\right]$ indolizino[1,2-b] quinolin-7-yl (morpholine-4-carbonyl)glycinate (12a)

The general synthetic method described above afforded compound $12 \mathrm{a}$ as a yellow solid $(78 \%)$. $\mathrm{mp}>250{ }^{\circ} \mathrm{C}$; HRMS (ESI): calcd for $\mathrm{C}_{28} \mathrm{H}_{26} \mathrm{~N}_{4} \mathrm{O}_{9} 563.5350$, found 563.1758. ${ }^{1} \mathrm{H}$ NMR (500 MHz, DMSO) $\delta 8.42(\mathrm{~s}, 1 \mathrm{H}), 7.46(\mathrm{~s}, 1 \mathrm{H}), 7.42(\mathrm{~s}, 1 \mathrm{H}), 7.14(t, J=5.7 \mathrm{~Hz}, 1 \mathrm{H}), 7.05(\mathrm{~s}, 1 \mathrm{H}), 6.27(\mathrm{~d}, J=4.8 \mathrm{~Hz}, 2 \mathrm{H}), 5.45$ $(\mathrm{s}, 2 \mathrm{H}), 5.15(\mathrm{~s}, 2 \mathrm{H}), 4.02(\mathrm{dd}, J=17.7,5.7 \mathrm{~Hz}, 1 \mathrm{H}), 3.90(\mathrm{dd}, J=17.8,5.8 \mathrm{~Hz}, 1 \mathrm{H}), 3.48(\mathrm{t}, J=4.7 \mathrm{~Hz}, 4 \mathrm{H})$, $3.25(\mathrm{dt}, J=13.5,6.6 \mathrm{~Hz}, 4 \mathrm{H}), 2.12(\mathrm{td}, J=13.8,7.0 \mathrm{~Hz}, 2 \mathrm{H}), 0.89(t, J=7.3 \mathrm{~Hz}, 3 \mathrm{H}) .{ }^{13} \mathrm{C} \mathrm{NMR}(125 \mathrm{MHz}$, DMSO) $\delta$ 170.50, 167.64, 157.76, 156.94, 151.85, 150.20, 149.12, 146.92, 146.68, 145.54, 130.58, 128.76, $126.05,118.48,105.01,103.53,103.06,95.08,76.45,66.76,66.35,50.49,44.21,42.44,30.93,7.93$.

(S)-7-ethyl-8,11-dioxo-7,8,11,13-tetrahydro-10H-[1,3]dioxolo[4,5-g]pyrano[3' $\left.4^{\prime}: 6,7\right]$ indolizino[1,2-b] quinolin-7-yl (piperidine-1-carbonyl)glycinate $(12 \mathrm{~b})$

The general synthetic method described above afforded compound $12 \mathrm{~b}$ as a yellow solid $(76 \%)$, $\mathrm{mp}>250{ }^{\circ} \mathrm{C}$; HRMS (ESI): calcd for $\mathrm{C}_{29} \mathrm{H}_{28} \mathrm{~N}_{4} \mathrm{O}_{8} 560.5634$, found $560.1875 .{ }^{1} \mathrm{H}$ NMR (500 MHz, DMSO) $\delta 8.42(\mathrm{~s}, 1 \mathrm{H}), 7.46(\mathrm{~s}, 1 \mathrm{H}), 7.42(\mathrm{~s}, 1 \mathrm{H}), 7.14(t, J=5.7 \mathrm{~Hz}, 1 \mathrm{H}), 7.05(\mathrm{~s}, 1 \mathrm{H}), 6.27(\mathrm{~d}, J=4.8 \mathrm{~Hz}, 2 \mathrm{H}), 5.45$ $(\mathrm{s}, 2 \mathrm{H}), 5.15(\mathrm{~s}, 2 \mathrm{H}), 4.02(\mathrm{dd}, J=17.7,5.7 \mathrm{~Hz}, 1 \mathrm{H}), 3.90(\mathrm{dd}, J=17.8,5.8 \mathrm{~Hz}, 1 \mathrm{H}), 3.48(t, J=4.7 \mathrm{~Hz}$, $4 \mathrm{H}), 3.25(\mathrm{dt}, J=13.5,6.6 \mathrm{~Hz}, 4 \mathrm{H}), 2.12(\mathrm{td}, J=13.8,7.0 \mathrm{~Hz}, 2 \mathrm{H}), 0.89(t, J=7.3 \mathrm{~Hz}, 3 \mathrm{H}) .{ }^{13} \mathrm{C} \mathrm{NMR}$ (125 MHz, DMSO) $\delta 172.96,170.72,167.68,157.47,156.95,151.81,150.21,149.06,146.63,145.65,130.58$, $128.71,126.01,118.43,105.23,103.52,96.32,95.26,76.38,72.85,66.73,65.67,50.58,44.69,42.68,30.66$, $25.80,24.51,8.24$. 
(S)-7-ethyl-8,11-dioxo-7,8,11,13-tetrahydro-10H-[1,3]dioxolo[4,5-g]pyrano[3' $4^{\prime}$ :6,7]indolizino[1,2-b] quinolin-7-yl (pyrrolidine-1-carbonyl)glycinate (12c)

The general synthetic method described above afforded compound $12 \mathrm{c}$ as a yellow solid $(76 \%)$, $\mathrm{mp}>250{ }^{\circ} \mathrm{C}$; HRMS (ESI): calcd for $\mathrm{C}_{28} \mathrm{H}_{26} \mathrm{~N}_{4} \mathrm{O}_{8} 547.5360$, found 547.1809. ${ }^{1} \mathrm{H}$ NMR (500 MHz, DMSO) $\delta 8.34(\mathrm{~d}, J=3.2 \mathrm{~Hz}, 1 \mathrm{H}), 7.36(\mathrm{~s}, 1 \mathrm{H}), 7.17(t, J=5.8 \mathrm{~Hz}, 1 \mathrm{H}), 7.13(\mathrm{~d}, J=8.0 \mathrm{~Hz}, 1 \mathrm{H}), 6.21(\mathrm{~d}, J=2.3 \mathrm{~Hz}$, $2 \mathrm{H}), 5.41(\mathrm{dd}, J=30.3,16.6 \mathrm{~Hz}, 2 \mathrm{H}), 4.94(\mathrm{dd}, J=22.9,12.8 \mathrm{~Hz}, 2 \mathrm{H}), 4.02(\mathrm{dd}, J=17.7,5.7 \mathrm{~Hz}, 1 \mathrm{H}), 3.96$ $-3.83(\mathrm{~m}, 1 \mathrm{H}), 3.71(\mathrm{~d}, J=14.6 \mathrm{~Hz}, 1 \mathrm{H}), 3.25(\mathrm{dt}, J=13.5,6.6 \mathrm{~Hz}, 4 \mathrm{H}), 2.12(\mathrm{td}, J=13.8,7.0 \mathrm{~Hz}, 2 \mathrm{H}), 1.87$ $-1.79(\mathrm{~m}, 1 \mathrm{H}), 1.53-1.30(\mathrm{~m}, 5 \mathrm{H}), 0.98(\mathrm{dd}, J=21.3,6.8 \mathrm{~Hz}, 3 \mathrm{H}) .{ }^{13} \mathrm{C}$ NMR $(125 \mathrm{MHz}, \mathrm{DMSO}) \delta 170.76$, $167.64,156.97,156.57,151.86,150.24,149.16,146.97,146.75,145.45,135.04,130.65,128.86,126.13,120.43$, $118.63,105.09,103.61,103.06,95.00,76.34,66.82,50.56,45.72,42.16,31.04,25.45,7.89$.

(S)-7-ethyl-8,11-dioxo-7,8,11,13-tetrahydro-10H-[1,3]dioxolo[4,5-g]pyrano[3' $4^{\prime}$ :6,7]indolizino[1,2-b] quinolin-7-yl (4-methylpiperazine-1-carbonyl)glycinate (12d)

The general synthetic method described above afforded compound $12 \mathrm{~d}$ as a yellow solid (36\%), mp 243-244 ${ }^{\circ} \mathrm{C}$; HRMS (ESI): calcd for $\mathrm{C}_{29} \mathrm{H}_{29} \mathrm{~N}_{5} \mathrm{O}_{8} 576.5780$, found 576.2073. ${ }^{1} \mathrm{H}$ NMR $(500 \mathrm{MHz}$, DMSO) $\delta 8.36(\mathrm{~s}, 1 \mathrm{H}), 7.37(\mathrm{~s}, 1 \mathrm{H}), 7.34(\mathrm{~s}, 1 \mathrm{H}), 7.10(\mathrm{~s}, 1 \mathrm{H}), 6.21(\mathrm{~d}, J=2.3 \mathrm{~Hz}, 2 \mathrm{H}), 5.42(\mathrm{q}, J=16.8 \mathrm{~Hz}$, 2H), $5.05(\mathrm{~s}, 2 \mathrm{H}), 4.03(\mathrm{~d}, J=17.9 \mathrm{~Hz}, 1 \mathrm{H}), 3.92(\mathrm{~d}, J=17.9 \mathrm{~Hz}, 1 \mathrm{H}), 3.36(\mathrm{~s}, 4 \mathrm{H}), 2.59(\mathrm{~s}, 4 \mathrm{H}), 2.36(\mathrm{~s}, 3 \mathrm{H})$, $2.08(\mathrm{dt}, J=24.0,7.0 \mathrm{~Hz}, 2 \mathrm{H}), 0.89(t, J=7.3 \mathrm{~Hz}, 3 \mathrm{H}) .{ }^{13} \mathrm{C} \mathrm{NMR}(125 \mathrm{MHz}, \mathrm{DMSO}) \delta 170.45,167.84$, 157.51, 157.15, 151.99, 149.78, 149.17, 146.67, 146.48, 146.10, 130.94, 128.51, 126.09, 118.22, 104.60, 103.48, $103.11,66.58,53.86,53.63,45.17,44.38,42.33,42.24,30.70,7.86$.

(S)-7-ethyl-8,11-dioxo-7,8,11,13-tetrahydro-10H-[1,3]dioxolo[4,5-g]pyrano[3' , $\left.^{\prime}: 6,7\right]$ indolizino[1,2-b] quinolin-7-yl (2-methylpiperidine-1-carbonyl)glycinate (12e)

The general synthetic method described above afforded compound 12e as a yellow solid (78\%), mp 240-242 ${ }^{\circ} \mathrm{C}$; HRMS (ESI): calcd for $\mathrm{C}_{30} \mathrm{H}_{30} \mathrm{~N}_{4} \mathrm{O}_{8} 575.5900$, found 575.2121. ${ }^{1} \mathrm{H}$ NMR $(500 \mathrm{MHz}$, DMSO) $\delta 8.28(\mathrm{~d}, J=3.2 \mathrm{~Hz}, 1 \mathrm{H}), 7.32-7.28(\mathrm{~m}, 1 \mathrm{H}), 7.25(\mathrm{~d}, J=10.6 \mathrm{~Hz}, 1 \mathrm{H}), 7.13(\mathrm{~d}, J=8.0 \mathrm{~Hz}, 1 \mathrm{H})$, $6.20(\mathrm{~d}, J=5.0 \mathrm{~Hz}, 2 \mathrm{H}), 5.41(\mathrm{dd}, J=30.3,16.6 \mathrm{~Hz}, 2 \mathrm{H}), 4.94(\mathrm{dd}, J=22.9,12.8 \mathrm{~Hz}, 2 \mathrm{H}), 4.07-3.97$ $(\mathrm{m}, 1 \mathrm{H}), 3.97-3.85(\mathrm{~m}, 1 \mathrm{H}), 3.71(\mathrm{~d}, J=14.6 \mathrm{~Hz}, 1 \mathrm{H}), 2.69(\mathrm{dt}, J=26.3,12.7 \mathrm{~Hz}, 1 \mathrm{H}), 2.14-2.01(\mathrm{~m}, 2 \mathrm{H})$, $1.87-1.79(\mathrm{~m}, 1 \mathrm{H}), 1.53-1.30(\mathrm{~m}, 5 \mathrm{H}), 0.98(\mathrm{dd}, J=21.3,6.8 \mathrm{~Hz}, 3 \mathrm{H}), 0.93-0.83(\mathrm{~m}, 3 \mathrm{H}) .{ }^{13} \mathrm{C}$ NMR (125 MHz, DMSO) 8 172.97, 170.74, 157.28, 156.98, 151.79, 150.51, 150.40, 149.09, 147.02, 146.36, 130.61, $128.86,126.05,118.53,105.27,103.56,103.03,96.34,76.40,72.86,65.69,55.37,50.62,45.60,38.35,30.68$, $18.75,15.74,8.24$.

(S)-7-ethyl-8,11-dioxo-7,8,11,13-tetrahydro-10H-[1,3]dioxolo[4,5-g]pyrano[3' $\left.4^{\prime}: 6,7\right]$ indolizino[1,2-b] quinolin-7-yl (thiomorpholine-4-carbonyl)glycinate (12f)

The general synthetic method described above afforded compound $12 \mathrm{f}$ as a yellow solid $(70 \%)$, $\mathrm{mp}>250{ }^{\circ} \mathrm{C}$; HRMS (ESI): calcd for $\mathrm{C}_{28} \mathrm{H}_{26} \mathrm{~N}_{4} \mathrm{O}_{8} \mathrm{~S} 579.5860$, found $579.1544 .{ }^{1} \mathrm{H}$ NMR $(500 \mathrm{MHz}$, DMSO) $\delta 8.43(\mathrm{~s}, 1 \mathrm{H}), 7.47(\mathrm{~s}, 1 \mathrm{H}), 7.42(\mathrm{~s}, 1 \mathrm{H}), 7.17(t, J=5.8 \mathrm{~Hz}, 1 \mathrm{H}), 7.09(\mathrm{~d}, J=5.9 \mathrm{~Hz}, 1 \mathrm{H}), 6.27$ $(\mathrm{d}, J=4.9 \mathrm{~Hz}, 2 \mathrm{H}), 5.46(\mathrm{~s}, 2 \mathrm{H}), 5.17(\mathrm{~d}, J=9.6 \mathrm{~Hz}, 2 \mathrm{H}), 4.01(\mathrm{dd}, J=17.7,5.7 \mathrm{~Hz}, 1 \mathrm{H}), 3.89(\mathrm{dd}, J=17.7$, $5.7 \mathrm{~Hz}, 1 \mathrm{H}), 3.59(\mathrm{ddd}, J=12.9,9.1,4.3 \mathrm{~Hz}, 3 \mathrm{H}), 3.29-3.25(\mathrm{~m}, 1 \mathrm{H}), 2.84-2.80(\mathrm{~m}, 1 \mathrm{H}), 2.46(\mathrm{t}, J=4.9 \mathrm{~Hz}$, $3 \mathrm{H}), 2.13(\mathrm{tt}, J=14.2,7.2 \mathrm{~Hz}, 2 \mathrm{H}), 0.91(t, J=7.4 \mathrm{~Hz}, 3 \mathrm{H}) .{ }^{13} \mathrm{C} \mathrm{NMR}(125 \mathrm{MHz}, \mathrm{DMSO}) \delta 170.56,167.66$, $157.18,156.97,151.85,150.23,149.13,146.94,146.69,145.65,130.58,128.78,126.05,118.42,105.03,103.55$, $103.06,95.20,76.49,66.74,50.52,46.54,45.21,42.70,30.91,26.55,24.08,7.97$.

\subsection{Biological Evalutation}

\subsubsection{Cell Culture}

Human colorectal cancer cell lines HCT-8, gastric cancer cell line MGC80-3, leukemia cell lines HL-60 and K562, pancreatic cancer cell line ASPC-1 and PNAC-1, hepatoma cell line HepG2, neuroglioma cell line U87, neuroblastoma cell line SH-SY5Y, NSCLC cell line A549, and SCLC cell 
line NCI-H446 were provided by the Institute of Biochemistry and Cell Biology, Chinese Academy of Sciences (Shanghai, China). NCI-H446, HCT-8, MGC80-3, and ASPC-1 were cultured in 1640 medium (Gibco, Grand Island, NY, USA), which were supplemented with 10\% FBS (Gibco, Grand Island, NY, USA), additional $25 \mathrm{mg} / \mathrm{L}$ glucose and $1 \mathrm{mM}$ sodium pyruvate (Solarbio, Beijing, China). HL-60 and HepG2 were maintained in 1640 supplemented with 10\% FBS. A549 cells were maintained in F12K medium (Gino, Hangzhou, China), which were supplemented with 10\% FBS. K562 cells were maintained in IMDM medium (Gibco, Grand Island, NY, USA) supplemented with 10\% FBS. PNAC-1 cells were maintained in DMEM medium (Gibco, Grand Island, NY, USA) supplemented with 10\% FBS. All cells were maintained in $5 \% \mathrm{CO}_{2}$ at $37^{\circ} \mathrm{C}$ and passaged every $2-4$ days.

\subsubsection{Cell Proliferation Assay}

Cell proliferation was measured by the SRB (Sigma, St. Louis, MO, USA) or 3-(4,5-Dimethylthiazol2-yl)-2,5-Diphenyltetrazolium Bromide reagent (MTT, Solarbio, Beijing, China) assay. Cells were seeded into 96-well plates, and treated with various concentrations of the indicated samples for $72 \mathrm{~h}$. MTT $(10 \mu \mathrm{L}, 5 \mathrm{mg} / \mathrm{mL})$ was added and incubated at $37^{\circ} \mathrm{C}$ for another $4 \mathrm{~h}$. The formazan product was dissolved and quantitated by spectrophotometry at a wavelength of $570 \mathrm{~nm}$. Inhibition rate of each sample was calculated from the A570 nm values as follows: Inhibition rate $(\%)=($ A570 $\mathrm{nm}$ control A570 nm sample)/A570 nm control $\times 100 \%$. For SRB assay, the cells are immobilized with TCA and tinted with SRB stain. The SRB stain that bound to cells was dissolved and quantitatively analyzed at a wavelength of $515 \mathrm{~nm}$. The cytotoxicity of compounds was expressed as $\mathrm{IC}_{50}$. All experiments were repeated at least three times.

\subsubsection{Hoechst 33342 Staining}

NCI-H446 cells and A549 cells were treated with 12e (0-100 Nm) for $24 \mathrm{~h}$, then were stained with Hoechst 33342 ( $5 \mu \mathrm{g} / \mathrm{mL}$, Sigma, St. Louis, MO, USA). The nuclear morphology was taken photos under fluorescence microscope.

\subsubsection{Clonogenic Assay}

NCI-H446 or A549 cells were seeded at 500 cells/well in 6-well plates, treated with various concentrations of $12 \mathrm{e}$ for 14 days. Fixed by methanol at room temperature and stained with Giemsa (Sigma, St. Louis, MO, USA) solution, colonies were defined as $\geq 50$ cells/colony. Finally, colonies were counted and photographed.

\subsubsection{Annexin V-FITC/PI Double-Staining Assay}

The apoptosis was performed using the Annexin V-FITC/PI apoptosis detection kit (Absin Bioscience Inc., Shanghai, China). Briefly, cells $\left(3 \times 10^{5}\right)$ were incubated with $12 \mathrm{e}(0-100 \mathrm{nM})$ for $24 \mathrm{~h}$, and then harvested by centrifugation, washed with ice-cold PBS twice, and resuspended in binding buffer. Staining was started by adding Annexin V-FITC $(5 \mu \mathrm{L})$ and PI $(5 \mu \mathrm{L})$ followed by incubation for $10 \mathrm{~min}$ at room temperature in the dark. Then, samples were immediately analyzed by NovoCyte flow cytometer (ACEA Biosciences, San Diego, CA, USA).

\subsubsection{Cell Cycle Analysis}

NCI-H446 and A549 cells were incubated with 12e (0-100 nM) for 24h. After that, the cells were collected and washed in PBS and fixed in ice-cold $70 \%(v / v)$ ethanol overnight at $-20{ }^{\circ} \mathrm{C}$. The cell pellet was resuspended in PBS and stained with a mixture of RNase $(10 \mu \mathrm{g} / \mathrm{mL}$, Solarbio, Beijing, China) and PI (50 $\mu \mathrm{g} / \mathrm{mL}$, Sigma, St. Louis, MO, USA) for $20 \mathrm{~min}$ in the dark. Cell cycle distribution analysis was performed using a MoFlo XDP flow cytometry system (Beckman Coulter, Boulevard Brea, CA, USA). 


\subsubsection{Western Blotting}

Cells were incubated with various concentrations of $12 \mathrm{e}$ for $24 \mathrm{~h}$ and then washed twice in cold phosphate buffered saline (PBS). Cells were lysed with lysis buffer (10 mM Tris, pH 7.4, $150 \mathrm{mM} \mathrm{NaCl}$, $1 \mathrm{mM}$ ethylenediaminetetraacetic acid (EDTA), 1\% Triton X-100, 0.5\% NP-40, $1 \mathrm{mM}$ propidium iodide (PI), $1 \mathrm{mM}$ dithiothreitol (DTT), $1 \mathrm{mM}$ phenylmethylsulfonyl fluoride (PMSF)) and placed on ice for $1 \mathrm{~h}$ with occasional vortex. Centrifugation followed at 10,000 rpm for $10 \mathrm{~min}$ and each cell lysate (50 $\mu \mathrm{g}$ ) was subjected to sodium dodecyl sulfate (SDS)-polyacrylamide gel electrophoresis (PAGE) and transferred to nitrocellulose membranes (Pall, New York, NY, USA). Blots were blocked with 5\% skim milk in TBST for $1 \mathrm{~h}$ at room temperature, then incubated with indicated primary antibodies (Cleaved Caspase-3, Cleaved Caspase-9, Cleaved PARP, Caspase-8, bax, Bcl-2, Mcl-1, survivin, $\gamma \mathrm{H} 2 \mathrm{AX}$, stat3, p-stat3, erk1/2, p-erk1/2, AKT, and p-AKT, 1:2000, Cell Signaling Technology, Danvers, MA, USA) overnight at $4{ }^{\circ} \mathrm{C}$, followed by incubation with anti-rabbit or anti-mouse horseradish peroxidase-conjugated immunoglobulin $\mathrm{G}(\mathrm{IgG})$ and visualized with enhanced chemiluminescence.

\subsubsection{RT-PCR}

Total RNA was extracted from cells treated with indicated concentrations of 12e for $24 \mathrm{~h}$ using RNAiso Plus (TaKaRa, Tokyo, Japan). Total RNA ( $2 \mu \mathrm{g}$ per sample) was converted to cDNA using $5 \times$ all in one RT mastermix (Abmgood, Zhenjiang, China) following the manufacturer's instructions. Individual reverse transcription reactions of $20 \mu \mathrm{L}$ were then diluted to $200 \mu \mathrm{L}$ with $\mathrm{ddH}_{2} \mathrm{O} .20 \mu \mathrm{L}$ of diluted RT reaction was used for real-time qPCR using the iTaq SYBR Green Supermix with ROX (Bio-Rad, Hercules, CA, USA). The sequences of primers used in real time qPCR reactions were as follows: $5^{\prime}$-TGGCGTAAGATGATGGA-3' (survivin forward) and 5'-TAGGGACGACGATGAAA-3' (survivin reverse), 5'-AACACGTACTTGTGCG-3' (XIAP forward) and 5'-ACTTTGATCTGGCTCA-3' (XIAP reverse), 5' -AAAGCCTGTCTGCCAAAT-3' (Mcl-1 forward) and 5'-TATAAACCCACCACTCCC-3' (Mcl-1 reverse), 5'-GCCTTCTTTGAGTTCG-3' (Bcl-2 forward) and $5^{\prime}$-CAGCCTCCGTTATCC-3' (Bcl-2 reverse). $\beta$-actin was used as an internal control. Triplicate qPCR reactions were performed for each of the samples. The real-time qPCR condition is $95^{\circ} \mathrm{C}$ for $2 \mathrm{~min}$ as a pre-denature step, followed by $40 \mathrm{PCR}$ cycles at $95^{\circ} \mathrm{C}$ for $10 \mathrm{~s}, 60^{\circ} \mathrm{C}$ for $45 \mathrm{~s}$ and $72{ }^{\circ} \mathrm{C}$ for $30 \mathrm{~s}$. The data were analyzed using the Applied Biosystems 7300 Real Time PCR System (Thermo Scientific, Waltham, MA, USA) and normalized to $\beta$-actin.

\subsubsection{DNA Relaxation Assay}

DNA relaxation assay was performed as described [40] with slight modification. In brief, a total of $20 \mu \mathrm{L}$ reaction containing pBR322 DNA $(0.5 \mu \mathrm{g})$, Topo I $(1 \mathrm{U}), 10 \times$ DNA Topo I Buffer $(2 \mu \mathrm{L}), 0.1 \%$ BSA $(2 \mu \mathrm{L})$ with or without the compound was incubated at $37^{\circ} \mathrm{C}$ for $30 \mathrm{~min}$. The reaction was terminated by adding $2 \mu \mathrm{L}$ of DNA $10 \times$ loading buffer and subjected to electrophoresis in $1 \%$ agarose. Then gels were stained with $3 \times$ GelRedTM Nucleic Acid Gel Stain and visualized by FluorChem E (Protein Simple, San Jose, CA, USA).

\subsubsection{In Vivo Studies}

Male BALB/c-nu mice (4 to 6 weeks of age) were purchased from Hunan SJA Laboratory Animal Co., Ltd. (Changsha, China). All animal experiments were approved by the Institutional Animal Care and Use Committee of Ocean University of China and according to standard institutional guidelines. $2 \times 10^{6} \mathrm{NCI}-\mathrm{H} 446$ or A549 cells were injected subcutaneously into the right flank of nude mice. The tumor volumes of these mice were checked to assess tumor growth. When the tumors reached about $100 \mathrm{~mm}^{3}$, the tumor-bearing mice were randomly allocated to various experimental group ( $n=5$, per group), and treated by intragastric administration with FL118, 12e, or vehicle. The formulation for FL118 and 12e in this study used the formulation recipe which contains FL118 or 
12e (1 mg/mL), DMSO (5\%), Tween-80 (4\%), HS-15 (4\%), and saline (87\%). The corresponding vehicle solution in the basic formulation recipe contains DMSO (5\%), Tween-80 (4\%), and HS-15 (4\%) in saline.

The mice body weights were weighed three times a week. The lengths (L) and widths (W) of tumors were measured three times a week using electronic calipers and the volumes $(\mathrm{V})$ was calculated as following formula: $\mathrm{V}=\left(\mathrm{L} \times \mathrm{W}^{2}\right) / 2$. When the tumor volume reached about $1000 \mathrm{~mm}^{3}$, tumors were excised, weighed, ground, and then disrupted on ice for $30 \mathrm{~min}$ in loading buffer, and boiled for $10 \mathrm{~min}$. Protein levels were analyzed by western blotting. The antitumor effect of the compounds was determined by inhibition rate (IR), which calculated according to the following equation: IR $(\%)=$ (tumor volume of control - tumor volume of compound)/(tumor volume of control-tumor volume of $\left.\mathrm{d}_{0}\right) \times 100 \%$.

\subsubsection{Data Analysis}

One-way ANOVA with Tukey's post hoc test was used for statistical analysis of the data, and values were expressed as mean \pm SD. Differences of $p<0.05$ were considered statistically significant.

Author Contributions: Conceptualization, J.L.; methodology, X.Q.; software, X.Q.; validation, X.D., G.W., Y.Z., X.Z. and R.Y.; formal analysis, X.D. and G.W.; investigation, X.D., G.W., Y.Z., X.Z. and R.Y.; resources, J.L.; data curation, X.Q.; writing—original draft preparation, X.D. and G.W.; writing-review and editing, J.L. and X.Q.; visualization, X.D. and G.W.; supervision, J.L.; project administration, X.Q. and T.J.; funding acquisition, J.L. All authors have read and agreed to the published version of the manuscript.

Funding: This research was funded by the National Natural Science Foundation of China [No. 81673450], National Natural Science Foundation of China-Shandong Joint Fund (U1906212, U1706213), the National Key R\&D Program of China (2019YFC0312504), National Science and Technology Major Project of China (2018ZX09735-004), the Marine S\&T Fund of Shandong Province for Pilot National Laboratory for Marine Science and Technology (Qingdao) (2018SDKJ0403). Shandong Provincial Natural Science Foundation (major basic research projects) [ZR2019ZD18], Shandong Provincial Natural Science Foundation (PhD Fund Project) [ZR2018BH039].

Acknowledgments: The authors are grateful for financial support granted by the National Natural Science Foundation of China [No. 81673450], National Natural Science Foundation of China-Shandong Joint Fund (U1906212, U1706213), the National Key R\&D Program of China (2019YFC0312504), National Science and Technology Major Project of China (2018ZX09735-004), the Marine S\&T Fund of Shandong Province for Pilot National Laboratory for Marine Science and Technology (Qingdao) (2018SDKJ0403). Shandong Provincial Natural Science Foundation (major basic research projects) [ZR2019ZD18].

Conflicts of Interest: The authors declare that they have no known competing financial interests or personal relationships that could have appeared to influence the work reported in this paper.

\section{References}

1. Bray, F.; Ferlay, J.; Laversanne, M.; Brewster, D.; Mbalawa, C.G.; Kohler, B.; Piñeros, M.; Steliarova-Foucher, E.; Swaminathan, R.; Antoni, S.; et al. Cancer Incidence in Five Continents: Inclusion criteria, highlights from Volume $X$ and the global status of cancer registration. Int. J. Cancer 2015, 137, 2060-2071. [CrossRef] [PubMed]

2. Arroyo, M.M.; Berral-González, A.; Bueno-Fortes, S.; Alonso-López, D.; Rivas, J.D.L. Mining Drug-Target Associations in Cancer: Analysis of Gene Expression and Drug Activity Correlations. Biomolecules 2020, 10, 667. [CrossRef] [PubMed]

3. Wall, M.E.; Wani, M.C.; Cook, C.E.; Palmer, K.H.; McPhail, A.T.; Sim, G.A. Plant Antitumor Agents. I. The Isolation and Structure of Camptothecin, a Novel Alkaloidal Leukemia and Tumor Inhibitor from Camptotheca acuminata1,2. J. Am. Chem. Soc. 1966, 88, 3888-3890. [CrossRef]

4. Liew, S.T.; Yang, L.-X. Design, synthesis and development of novel camptothecin drugs. Curr. Pharm. Des. 2008, 14, 1078-1097. [CrossRef] [PubMed]

5. Li, Q.-Y.; Zu, Y.-G.; Shi, R.-Z.; Yao, L.-P. Review Camptothecin: Current Perspectives. Curr. Med. Chem. 2006, 13, 2021-2039. [CrossRef] [PubMed]

6. Zunino, F.; Dallavalle, S.; Laccabue, D.; Beretta, G.L.; Merlini, L.; Pratesi, G. Current Status and Perspectives in the Development of Camptothecins. Curr. Pharm. Des. 2002, 8, 2505-2520. [CrossRef] [PubMed] 
7. Ling, X.; Cao, S.; Cheng, Q.; Keefe, J.T.; Rustum, Y.M.; Li, F. A Novel Small Molecule FL118 That Selectively Inhibits Survivin, Mcl-1, XIAP and cIAP2 in a p53-Independent Manner, Shows Superior Antitumor Activity. PLoS ONE 2012, 7, e45571. [CrossRef] [PubMed]

8. Li, F.; Ackermann, E.J.; Bennett, C.F.; Rothermel, A.L.; Plescia, J.; Tognin, S.; Villa, A.; Marchisio, P.C.; Altieri, D.C. Pleiotropic cell-division defects and apoptosis induced by interference with survivin function. Nat. Cell Biol. 1999, 1, 461-466. [CrossRef]

9. Li, F.; Ling, X. Survivin Study: An update of "What is the next wave?". J. Cell. Physiol. 2006, 208, 476-486. [CrossRef]

10. Zhao, J.; Ling, X.; Cao, S.; Liu, X.; Wan, S.; Jiang, T.; Li, F. Antitumor Activity of FL118, a Survivin, Mcl-1, $\mathrm{XIAP}$, and cIAP2 Selective Inhibitor, Is Highly Dependent on Its Primary Structure and Steric Configuration. Mol. Pharm. 2014, 11, 457-467. [CrossRef]

11. Ling, X.; Xu, C.; Fan, C.; Zhong, K.; Li, F.; Wang, X. FL118 Induces p53-Dependent Senescence in Colorectal Cancer Cells by Promoting Degradation of MdmX. Cancer Res. 2014, 74, 7487-7497. [CrossRef] [PubMed]

12. Wu, G.; Mai, X.; Liu, F.; Lin, M.; Dong, X.; Xu, Q.; Hao, C.; Zhang, L.; Yu, R.; Jiang, T. Synthesis of novel 10,11-methylenedioxy-camptothecin glycoside derivatives and investigation of their anti-tumor effects in vivo. RSC Adv. 2019, 9, 11142-11150. [CrossRef]

13. Wani, M.C.; Nicholas, A.W.; Manikumar, G.; Wall, M.E. Plant antitumor agents. 25. Total synthesis and antileukemic activity of ring A substituted camptothecin analogs. Structure-activity correlations. J. Med. Chem. 1987, 30, 1774-1779. [CrossRef] [PubMed]

14. DiSaia, P.J.; Sinkovics, J.G.; Rutledge, F.N.; Smith, J.P. Cell-mediated immunity to human malignant cells. Am. J. Obstet. Gynecol. 1972, 114, 979-989. [CrossRef]

15. Adamovics, J.A.; Hutchinson, C.R. Prodrug analogs of the antitumor alkaloid camptothecin. J. Med. Chem. 1979, 22, 310-314. [CrossRef]

16. Yaegashi, T.; Sawada, S.; Nagata, H.; Furuta, T.; Yokokura, T.; Miyasaka, T. Synthesis and Antitumor Activity of 20(S)-Camptothecin Derivatives. A-Ring-Substituted 7-Ethylcamptothecins and Their E-Rig-Modified Water-Soluble Derivatives. Chem. Pharm. Bull. 1994, 42, 2518-2525. [CrossRef]

17. Zhao, T.; Lv, H.; Zu, Y.; Qu, Z.; Yao, L.; Su, L.; Liu, C.; Wang, L. Synthesis and antitumor activity of novel 20s-camptothecin analogues. Bioorg. Med. Chem. Lett. 2009, 19, 513-515. [CrossRef]

18. Wang, M.-J.; Liu, Y.-Q.; Chang, L.-C.; Wang, C.-Y.; Zhao, Y.-L.; Zhao, X.-B.; Qian, K.; Nan, X.; Yang, L.; Yang, X.-M.; et al. Design, Synthesis, Mechanisms of Action, and Toxicity of Novel 20(S)-Sulfonylamidine Derivatives of Camptothecin as Potent Antitumor Agents. J. Med. Chem. 2014, 57, 6008-6018. [CrossRef]

19. Song, Z.-L.; Wang, M.-J.; Li-Ting, Y.; Wu, D.; Wang, Y.-H.; Yan, L.-T.; Morris-Natschke, S.L.; Liu, Y.-Q.; Zhao, Y.-L.; Wang, C.-Y.; et al. Design, synthesis, cytotoxic activity and molecular docking studies of new 20(S)-sulfonylamidine camptothecin derivatives. Eur. J. Med. Chem. 2016, 115, 109-120. [CrossRef]

20. Zhao, H.; Lee, C.; Sai, P.; Choe, Y.H.; Boro, M.; Pendri, A.; Guan, S.; Greenwald, R.B. 20-O-acylcamptothecin derivatives: Evidence for lactone stabilization. J. Org. Chem. 2000, 65, 4601-4606. [CrossRef]

21. Yang, L.-X.; Pan, X.; Wang, H.-J. Novel camptothecin derivatives. Part 1: Oxyalkanoic acid esters of camptothecin and their in vitro and in vivo antitumor activity. Bioorg. Med. Chem. Lett. 2002, 12, 1241-1244. [CrossRef]

22. De Groot, F.M.H.; Busscher, G.F.; Aben, R.W.M.; Scheeren, H.W. Novel 20-carbonate linked prodrugs of camptothecin and 9-aminocamptothecin designed for activation by tumour-associated plasmin. Bioorg. Med. Chem. Lett. 2002, 12, 2371-2376. [CrossRef]

23. Lerchen, H.G.; Baumgarten, J.; dem Bruch, K.; Lehmann, T.E.; Sperzel, M.; Kempka, G.; Fiebig, H.H. Synthesis of 20-O-linked 20(S)-camptothecin Glycoconjugates: Impact of the side chain of the ester-linked amino acid on epimerization during the acylation reaction and on hydrolytic stability of the final glycoconjugates. J. Med. Chem. 2001, 44, 4186-4195. [CrossRef] [PubMed]

24. Lum, C.; Alamgeer, M. Lum Technological and Therapeutic Advances in Advanced Small Cell Lung Cancer. Cancers 2019, 11, 1570. [CrossRef]

25. Ling, X.; Liu, X.; Zhong, K.; Smith, N.; Prey, J.; Li, F. FL118, a novel camptothecin analogue, overcomes irinotecan and topotecan resistance in human tumor xenograft models. Am. J. Transl. Res. 2015, 7, 1765-1781.

26. Rabi, T.; Li, F. Multiple mechanisms involved in a low concentration of FL118 enhancement of AMR-MeOAc to induce pancreatic cancer cell apoptosis and growth inhibition. Am. J. Cancer Res. 2018, 8, 2267-2283. 
27. Yang, Z.; Ji, L.; Jiang, G.; Liu, R.; Liu, Z.; Yang, Y.Q.; Ma, H.Z. FL118, a novel camptothecin analogue, suppressed migration and invasion of human breast cancer cells by inhibiting epithelial-mesenchymal transition via the Wnt/ $\beta$-catenin signaling pathway. Biosci. Trends 2018, 12, 40-46. [CrossRef]

28. Elmore, S. Apoptosis: A Review of Programmed Cell Death. Toxicol. Pathol. 2007, 35, 495-516. [CrossRef]

29. Ling, X.; Wu, W.; Fan, C.; Xu, C.; Liao, J.; Rich, L.J.; Huang, R.-Y.; Repasky, E.A.; Wang, X.; Li, F. An ABCG2 non-substrate anticancer agent FL118 targets drug-resistant cancer stem-like cells and overcomes treatment resistance of human pancreatic cancer. J. Exp. Clin. Cancer Res. 2018, 37, 240. [CrossRef]

30. Bröker, L.E.; Kruyt, F.A.; Giaccone, G. Cell Death Independent of Caspases: A Review. Clin. Cancer Res. 2005, 11, 3155-3162. [CrossRef]

31. Yu, J.W.; Shi, Y. FLIP and the death effector domain family. Oncogene 2008, 27, 6216-6227. [CrossRef] [PubMed]

32. Demchenko, A.P. The change of cellular membranes on apoptosis: Fluorescence detection. Exp. Oncol. 2012, 34, 263-268. [PubMed]

33. Hirano, T.; Ishihara, K.; Hibi, M. Roles of STAT3 in mediating the cell growth, differentiation and survival signals relayed through the IL-6 family of cytokine receptors. Oncogene 2000, 19, 2548-2556. [CrossRef] [PubMed]

34. Little, A.; Smith, P.; Cook, S. Mechanisms of acquired resistance to ERK1/2 pathway inhibitors. Oncogene 2013, 32, 1207-1215. [CrossRef] [PubMed]

35. Guo, Y.; Pan, W.; Liu, S.; Shen, Z.; Xu, Y.; Hu, L. ERK/MAPK signalling pathway and tumorigenesis (Review). Exp. Ther. Med. 2020, 19, 1997-2007. [CrossRef] [PubMed]

36. Castedo, M.; Perfettini, J.-L.; Roumier, T.; Andreau, K.; Medema, R.; Kroemer, G. Cell death by mitotic catastrophe: A molecular definition. Oncogene 2004, 23, 2825-2837. [CrossRef]

37. Li, F.; Jiang, T.; Li, Q.; Ling, X. Camptothecin (CPT) and its derivatives are known to target topoisomerase I (Top1) as their mechanism of action: Did we miss something in CPT analogue molecular targets for treating human disease such as cancer? Am. J. Cancer Res. 2017, 7, 2350-2394.

38. Chan, K.T.; Meng, F.Y.; Li, Q.; Ho, C.Y.; Lam, T.S.; To, Y.; Lee, W.H.; Li, M.; Chu, K.H.; Toh, M. Cucurbitacin B induces apoptosis and S phase cell cycle arrest in BEL-7402 human hepatocellular carcinoma cells and is effective via oral administration. Cancer Lett. 2010, 294, 118-124. [CrossRef]

39. Steelman, L.S.; Abrams, S.L.; Whelan, J.E.; Bertrand, F.E.; Ludwig, D.; Bäsecke, J.; Libra, M.; Stivala, F.; Milella, M.; Tafuri, A.; et al. Contributions of the Raf/MEK/ERK, PI3K/PTEN/Akt/mTOR and Jak/STAT pathways to leukemia. Leukemia 2008, 22, 686-707. [CrossRef]

40. Böğürcü-Seidel, N.; Sevimli-Gur, C.; Ozmen, B.; Bedir, E.; Korkmaz, K.S. ALCAPs induce mitochondrial apoptosis and activate DNA damage response by generating ROS and inhibiting topoisomerase I enzyme activity in K562 leukemia cell line. Biochem. Biophys. Res. Commun. 2011, 409, 738-744. [CrossRef]

Publisher's Note: MDPI stays neutral with regard to jurisdictional claims in published maps and institutional affiliations.

(C) 2020 by the authors. Licensee MDPI, Basel, Switzerland. This article is an open access article distributed under the terms and conditions of the Creative Commons Attribution (CC BY) license (http://creativecommons.org/licenses/by/4.0/). 